\title{
Economic Analysis of the Reference Design for a Nuclear-Driven High- Temperature-Electrolysis Hydrogen Production Plant
}

E. A. Harvego

M. G. McKellar

M. S. Sohal

J. E. O'Brien

J. S. Herring

January 2008

The INL is a U.S. Department of Energy National Laboratory operated by Battelle Energy Alliance

Idaho National Laboratory 
INL/EXT-08-13799

\title{
Economic Analysis of the Reference Design for a Nuclear-Driven High-Temperature-Electrolysis Hydrogen Production Plant
}

\author{
E. A. Harvego \\ M. G. McKellar \\ M. S. Sohal \\ J. E. O'Brien \\ J. S. Herring \\ January 2008 \\ Idaho National Laboratory
Idaho Falls, Idaho 83415 \\ Prepared for the \\ U.S. Department of Energy \\ Office of Nuclear Energy \\ Under DOE Idaho Operations Office \\ Contract DE-AC07-05ID14517
}




\begin{abstract}
A reference design for a commercial-scale high-temperature electrolysis (HTE) plant for hydrogen production was developed to provide a basis for comparing the HTE concept with other hydrogen production concepts. The reference plant design is driven by a high-temperature helium-cooled reactor coupled to a direct Brayton power cycle. The reference design reactor power is $600 \mathrm{MWt}$, with a primary system pressure of $7.0 \mathrm{MPa}$, and reactor inlet and outlet fluid temperatures of $540^{\circ} \mathrm{C}$ and $900^{\circ} \mathrm{C}$, respectively. The electrolysis unit used to produce hydrogen consists of 4,009,177 cells with a per-cell active area of $225 \mathrm{~cm}^{2}$. A nominal cell area-specific resistance, $A S R$, value of $0.4 \mathrm{Ohm} \cdot \mathrm{cm}^{2}$ with a current density of $0.25 \mathrm{~A} / \mathrm{cm}^{2}$ was used, and isothermal boundary conditions were assumed. The optimized design for the reference hydrogen production plant operates at a system pressure of 5.0 MPa, and utilizes an air-sweep system to remove the excess oxygen that is evolved on the anode side of the electrolyzer. The inlet air for the air-sweep system is compressed to the system operating pressure of 5.0 MPa in a four-stage compressor with intercooling. The alternating-current to direct-current conversion efficiency is assumed to be $96 \%$. The overall system thermal-to-hydrogen production efficiency (based on the low heating value of the produced hydrogen) is $47.12 \%$ at a hydrogen production rate of $2.356 \mathrm{~kg} / \mathrm{s}$.
\end{abstract}

An economic analysis of the plant was also performed using the H2A Analysis Methodology developed by the Department of Energy (DOE) Hydrogen Program. The results of the economic analysis demonstrated that the HTE hydrogen production plant driven by a high-temperature helium-cooled nuclear power plant can deliver hydrogen at a competitive cost using realistic financial and cost estimating assumptions. A plant-gate cost of $\$ 3.23$ per $\mathrm{kg}$ of hydrogen produced was calculated assuming an internal rate of return of $10 \%$. Approximately $73 \%$ of this cost $(\$ 2.36 / \mathrm{kg})$ is the result of capital costs associated with the construction of the combined nuclear plant and hydrogen production facility. Operation and maintenance costs represent about $18 \%$ of the total cost $(\$ 0.57 / \mathrm{kg})$. Variable costs (including the cost of nuclear fuel) contribute about $8.7 \%(\$ 0.28 / \mathrm{kg})$ to the total cost of hydrogen production, and decommissioning and raw material costs make up the remaining fractional cost. 


\section{Table of Contents}

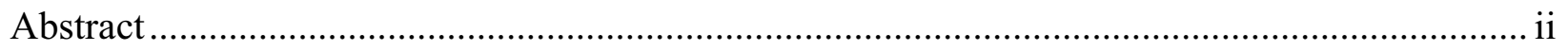

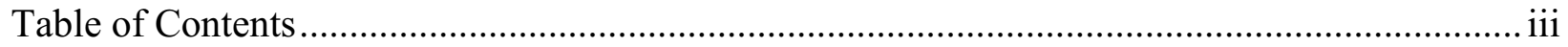

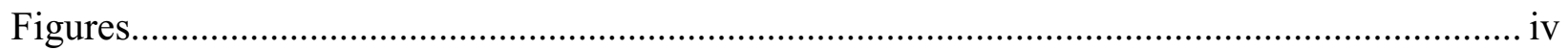

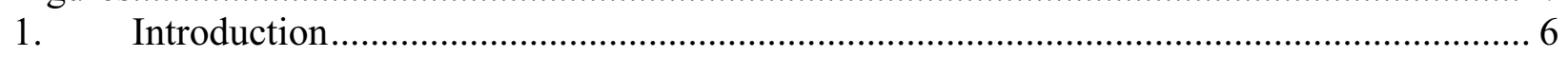

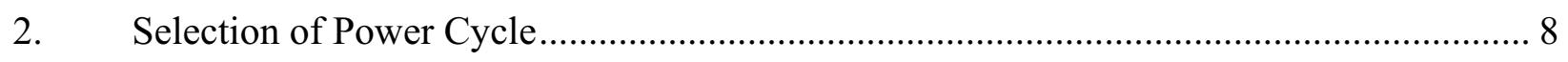

2.1. Direct Helium Recuperated Brayton Cycle .................................................... 8

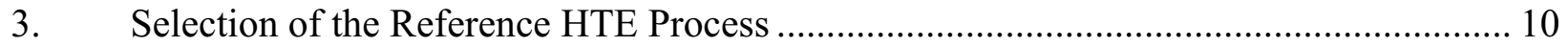

4. Coupling of the HTE Plant and Reactor Power Cycle ................................................ 11

5. Reference Design Conditions ................................................................................... 14

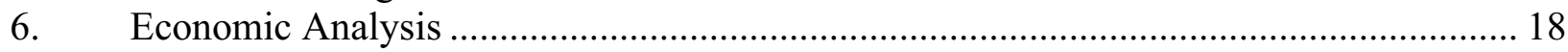

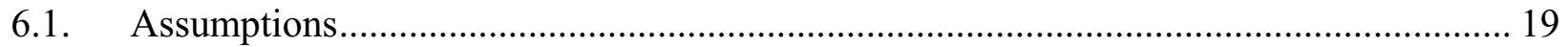

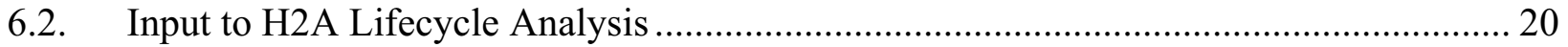

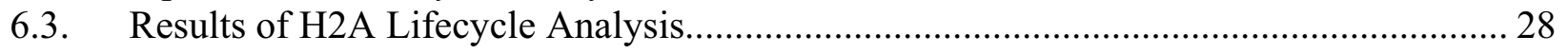

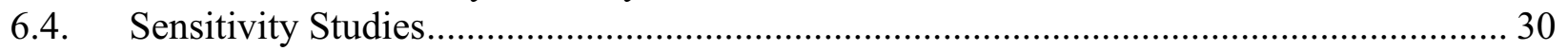

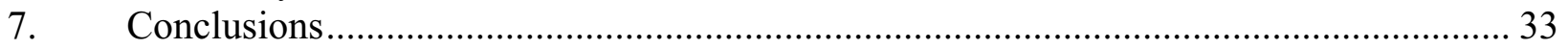

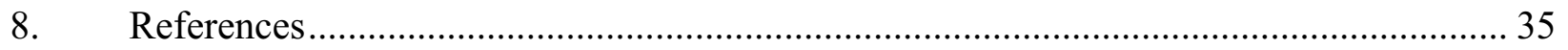




\section{Figures}

Figure 1. UniSim process flow diagram for helium recuperated direct Brayton cycle. ....................................9

Figure 2. Process flow diagram for helium-cooled reactor/direct Brayton/HTE system with air sweep. ............12

Figure 3. Process flow diagram of electrolyzer model.............................................................................

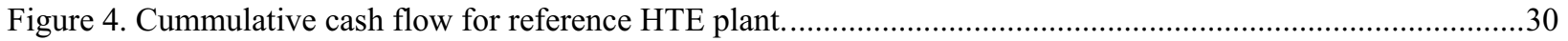

Figure 5. Calculated hydrogen production cost as a function of internal rate of return..............................................31

Figure 6. Tornado plot showing sensitivity of hydrogen cost to parameter variations...............................................32 


\section{Tables}

Table 1. Stream fluid conditions and flow rates for reference plant design. ...................... 15

Table 2. Mole fraction composition data for reference plant design. ................................ 16

Table 3. Component heat rates and electrolysis power for reference design...................... 17

Table 4. Heat exchanger design parameters for reference plant design............................. 17

Table 5. Turbine design parameters for reference plant design...................................... 17

Table 6. Compressor design parameters for reference plant design. ................................ 17

Table 7. Pump design parameters for reference plant design. ........................................... 17

Table 8. Basic financial assumptions for reference HTE plant design.............................. 21

Table 9. Start up and decommissioning assumptions for reference plant design................. 22

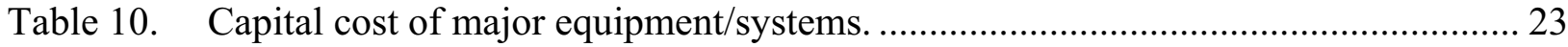

Table 11. Indirect depreciable capital costs.......................................................... 26

Table 12. Fixed O\&M costs for reference plant design................................................. 27

Table 13. Summary of capital investment costs (FY2005 \$) ............................................ 28

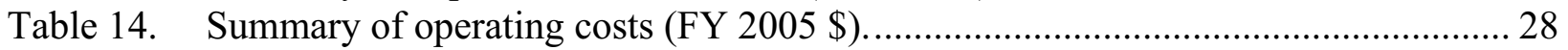

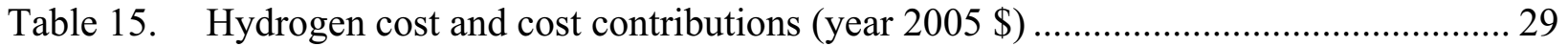




\section{Introduction}

This report presents results of a lifecycle cost analysis of the reference design for a commercialscale high-temperature electrolysis (HTE) plant for hydrogen production. The primary advantage of high temperature electrolysis over conventional electrolysis, which is a well established technology, is that considerably higher overall efficiencies can be achieved. The improved performance of HTE versus conventional low-temperature (alkaline or PEM) electrolysis is due to both the improved power-cycle efficiencies and electrolyzer efficiencies associated with high-temperature operation. Higher reactor outlet temperatures yield higher power cycle efficiencies in accordance with the Carnot principle. For example, power conversion thermal efficiencies in excess of $50 \%$ can be achieved with the high-temperature gascooled reactor coupled to the direct Brayton cycle [1]. The electrolyzer itself benefits from hightemperature operation for reasons related to both thermodynamics and electrochemical kinetics. From thermodynamics, the electrical energy requirement for water or steam electrolysis decreases with increasing temperature, while the thermal energy requirement increases. Consequently, at higher temperatures, a larger fraction of the total electrolysis energy input can be supplied in the form of heat, increasing the overall process efficiency. In terms of electrochemical kinetics, activation and ohmic overpotentials also decrease dramatically with temperature.

UniSim process-analysis software was used in the optimization of the commercial-scale hydrogen production plant coupled to a high-temperature helium-cooled reactor. UniSim software is a derivative of the HYSYS process analysis software. UniSim inherently ensures mass and energy balances across all components and it includes thermodynamic data for all chemical species. The optimized design described in this report is based on analyses of process flow diagrams that include realistic representations of the reactor power source coupled to the Brayton power cycle and integrated with the high-temperature electrolysis process loops. As with previous HTE system analyses performed at the INL, a custom electrolyzer model was incorporated into the overall process flow sheet. This electrolyzer model allows for the determination of the average Nernst potential, cell operating voltage, gas outlet temperatures, and electrolyzer efficiency for any specified inlet steam, hydrogen, and sweep-gas flow rates, current density, cell active area, and external heat loss or gain. The electrolyzer model has been validated by comparison with results obtained from a fully 3 -D computational fluid dynamics model and by comparison with experimental results. These comparisons may be found in Reference [2].

The lifecycle cost analysis was performed using the H2A analysis methodology developed by the Department of Energy (DOE) Hydrogen Program. This methodology utilizes a spreadsheet analysis tool that requires detailed plant performance information, along with financial and cost information to calculate lifecycle costs. There are a standard set of assumptions (discussed later) that the methodology uses to ensure consistency when comparing the cost of different production or plant design options. However, these assumptions may also be varied within the spreadsheet to allow the performance of sensitivity studies. The following sections begin with a discussion of the reference INL HTE design concept along with operating conditions and performance parameters used to develop the lifecycle cost estimate. Required inputs for the lifecycle cost 
estimate are then presented, along with the results of the estimated hydrogen production costs ( $\$ / \mathrm{kg}$ of hydrogen), the sensitivity of hydrogen production costs to several critical parameters, and the conclusions of the study. 


\section{Selection of Power Cycle}

The selection of the reactor power cycle was based on previous parametric studies performed at the INL $[3,4]$. In these previous studies, three advanced reactor - power cycle combinations were analyzed, including: a high-temperature helium-cooled reactor coupled to a direct helium recuperated Brayton cycle, a supercritical $\mathrm{CO}_{2}$-cooled reactor coupled to a direct supercritical $\mathrm{CO}_{2}$ recompression cycle, and a sodium-cooled fast reactor coupled to a tertiary steam Rankine cycle.

The three reactor power cycles evaluated were based on advanced reactor concepts capable of operating with reactor outlet temperatures in the range of $550^{\circ} \mathrm{C}$ to $900^{\circ} \mathrm{C}$. These high temperatures result in higher power cycle efficiencies (33 to 55\%) for these advanced reactor concepts than can be achieved with current generation light water reactors (30 to 35\%). In addition, the high temperature process heat available from these advanced high temperature reactors can further enhance hydrogen production efficiencies when the reactor is directly coupled to a HTE hydrogen production plant.

The results of these studies showed that a high-temperature gas-cooled reactor directly coupled to a helium-recuperated Brayton cycle produced higher overall thermal-to-hydrogen production efficiencies (in the range of 45 - 50\% efficiency) when compared to the supercritical $\mathrm{CO}_{2}$-cooled reactor utilizing a direct recompression power cycle $(42-44 \%$ hydrogen production efficiency) and a sodium-cooled reactor utilizing an indirect Rankine cycle $(33-34 \%$ hydrogen production efficiency).

Based on these results, a helium-cooled high-temperature gas-cooled reactor coupled to a direct helium recuperated Brayton power cycle was selected as the reference power source. This power system is described in more detail below.

\subsection{Direct Helium Recuperated Brayton Cycle}

A process flow diagram for the high-temperature helium-cooled reactor coupled to the direct helium recuperated Brayton cycle is presented in Figure 1. This UniSim power-cycle model was initially described in [4]. The primary helium coolant exits the reactor at $900^{\circ} \mathrm{C}$. This helium flow is split at T1, with more than $85 \%$ of the flow directed toward the power cycle and the remainder directed to the intermediate heat exchanger to provide process heat to the HTE loop. Within the power-cycle loop, helium flows through the power turbine where the gas is expanded to produce electric power. The helium, at a reduced pressure and temperature, then passes through a recuperator and precooler where it is further cooled before entering the low-pressure compressor. To improve compression efficiencies, the helium is again cooled in an intercooler heat exchanger before entering the high-pressure compressor. The helium exits the highpressure compressor at a pressure that is slightly higher than the reactor operating pressure of 7 $\mathrm{MPa}$. The coolant then circulates back through the recuperator where the recovered heat raises its temperature to the reactor inlet temperature of $540^{\circ} \mathrm{C}$, completing the cycle. 
Process heat for the HTE hydrogen production plant is provided by splitting the reactor coolant outlet flow into two streams, and allowing a fraction (typically less than 15\%) of the flow to pass through an intermediate heat exchanger where heat is extracted for use in the hydrogen

production process. The cooler helium leaving the intermediate heat exchanger (stream 3 in Figure 1) is then returned through a circulator to the reactor inlet pressure and mixed with the primary coolant returning to the reactor.

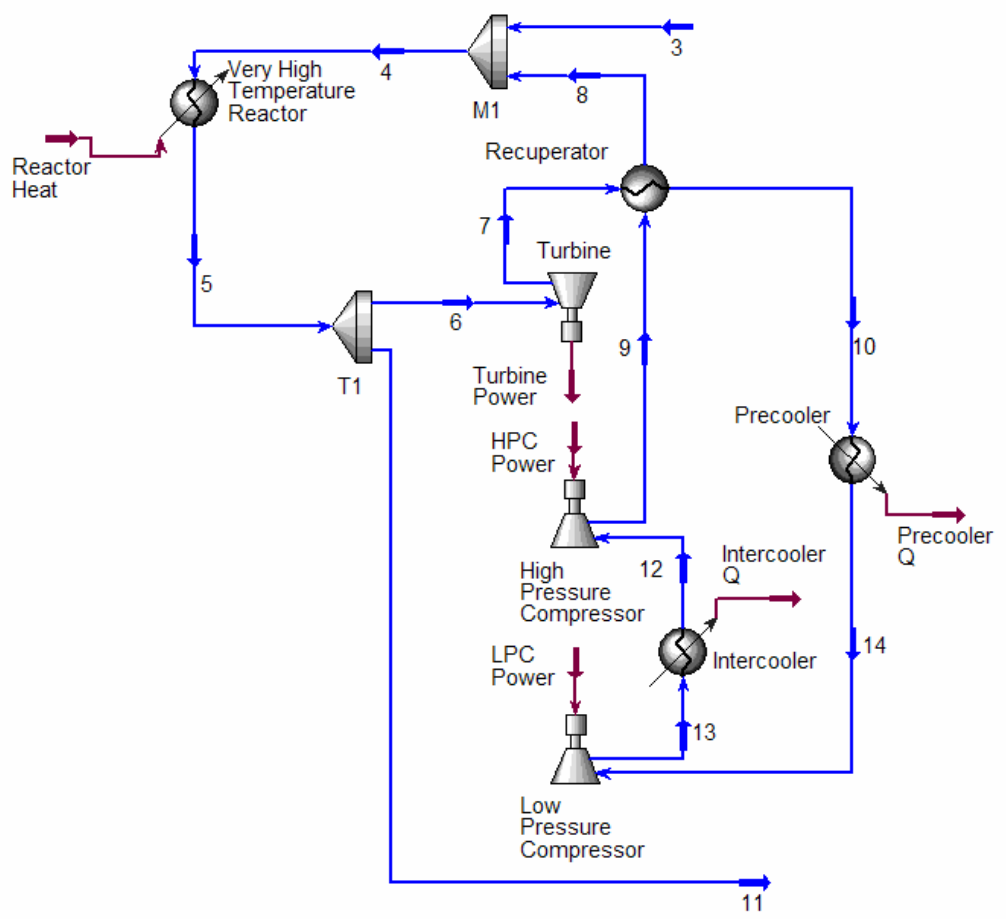

Figure 1. UniSim process flow diagram for helium recuperated direct Brayton cycle.

The reactor thermal power assumed for the high-temperature helium-cooled reactor was 600 MWt. The UniSim-calculated power cycle thermal efficiency for the system represented in Figure 1 is $53.23 \%$. 


\section{Selection of the Reference HTE Process}

Parametric studies evaluating the coupling of various reactor concepts with the HTE hydrogen production plant are described in References [3 and 4]. These studies included operating the HTE plant at pressures of $3.5 \mathrm{MPa}$ and $7.0 \mathrm{MPa}$ and with and without the use of sweep gas to remove the excess oxygen from the anode side of the electrolyzer. An integral part of all of these parametric studies was the optimization of hydrogen production rates and efficiencies using realistic operating parameters for the various components within the system.

Based on the results of these parametric studies, a gas-sweep system was selected for the reference design. While slightly higher overall hydrogen production efficiencies (increase of 1.0 $-1.5 \%$ ) can be achieved when no gas sweep system is used, concerns with the handling of the high temperature oxygen product gas led to the decision to use a gas-sweep system for oxygen removal from the electrolyzer anode [3]. Two types of gas-sweep systems, an air-sweep and a steam-sweep, were evaluated. The steam-sweep system was initially considered because of the relative ease of separating the steam and oxygen by condensation so that the oxygen product gas might be used for other commercial applications. However, the steam-sweep system unduly complicated the design of the HTE plant and individual components and, therefore, the HTE plant with an air-sweep system was selected as the reference design.

The operating pressure of the HTE plant was also evaluated because higher operating pressures result in smaller components and/or lower system pressure drops for a given mass flow rate. However, higher system pressures also require heavier and more expensive components, and can have a negative impact on system performance and reliability. Based on these considerations, and the results of analyses performed at system operating pressures of $3.5 \mathrm{MPa}$ and $7.0 \mathrm{MPa}$ which indicated slightly lower overall hydrogen production efficiencies at the higher HTE operating pressure [2], an HTE operating pressure of 5.0 $\mathrm{MPa}$ was selected for the reference design. The decision to operate at $5.0 \mathrm{MPa}$ was also influenced by the need to deliver the hydrogen gas at elevated pressure for either storage or pipeline transport. Therefore, from the standpoint of overall process efficiency, it is logical to compress the liquid water feedstock at the process inlet since liquid-phase compression work is very small compared to compression of the gaseous product. Any comparison made to the HTE reference process described here should also refer to delivery of the product hydrogen at 5.0 MPa.

Based on the above considerations, a description of the finalized reference reactor power cycle and coupled HTE hydrogen production plant design used in the H2A lifecycle cost analysis is provided in the following section. 


\section{Coupling of the HTE Plant and Reactor Power Cycle}

The overall process flow diagram for the very high-temperature helium-cooled reactor coupled to the direct helium Brayton power cycle and the HTE plant with air sweep is presented in Figure 2. The liquid water feedstock enters at the left in the diagram. The water is then compressed to the HTE process pressure of 5.0 MPa in the liquid phase using a pump.

Downstream of the pump, condensate from the water knockout tank is recycled back into the inlet stream at M3. The water stream is then vaporized and pre-heated in the electrolysis recuperator, which recovers heat from the post-electrolyzer process and sweep-gas outlet streams. Downstream of the recuperator, at M2, the steam is mixed with recycled hydrogen product gas. A fraction of the product gas is recycled in this way in order to assure that reducing conditions are maintained on the steam/hydrogen electrode. Downstream of the mixer, the process gas mixture enters the intermediate heat exchanger (IHX), where final heating to the electrolysis operating temperature occurs, using high-temperature process heat from the nuclear reactor. The process stream then enters the electrolyzer, where oxygen is electrolytically removed from the steam, producing hydrogen and oxygen. An additional process heater is used to directly add heat during the electrolysis process to maintain isothermal electrolyzer operating conditions. 


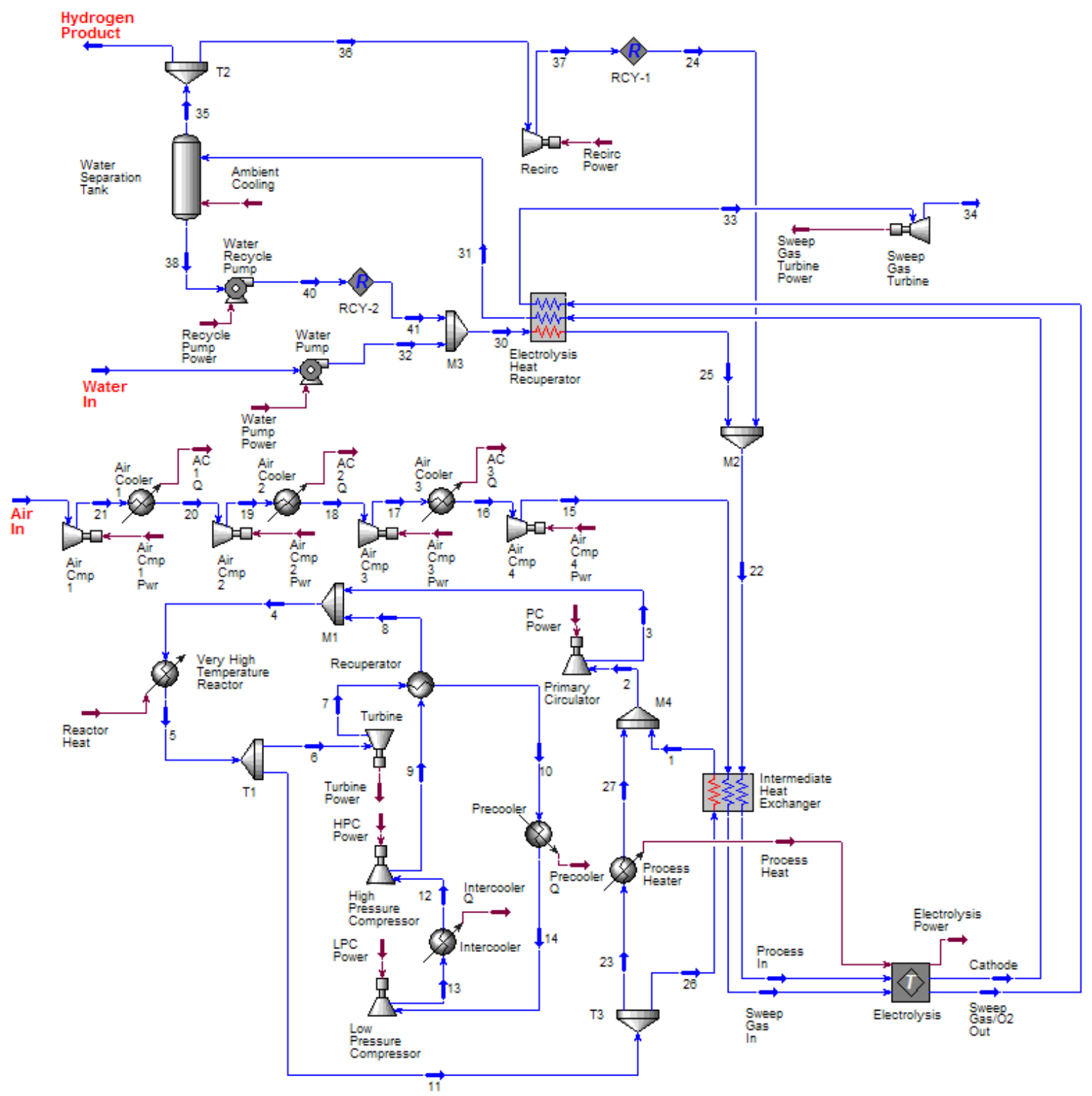

Figure 2. Process flow diagram for helium-cooled reactor/direct Brayton/HTE system with air sweep.

Downstream of the electrolyzer, the hydrogen - rich product stream flows through the electrolysis recuperator where the product stream is cooled and the inlet process stream is preheated. The product stream is cooled further at the water knockout tank, where the majority of any residual steam is condensed and separated, and yielding dry hydrogen product. The cooled product stream is split at $\mathrm{T} 2$ and a fraction of the product gas is recycled into the inlet process stream, as discussed previously. A recirculating blower is required to repressurize the recycle stream to the upstream pressure at M2.

The process flow diagram shows air in use as a sweep gas to remove the excess oxygen that is evolved on the anode side of the electrolyzer. In the air sweep system, inlet air is compressed to 
the system operating pressure of 5.0 MPa in a four-stage compressor with intercooling. The final compression stage is not followed by a cooler, so the air enters the $\mathrm{IHX}$ at about $171^{\circ} \mathrm{C}$. The sweep gas is heated to the electrolyzer operating temperature of $800^{\circ} \mathrm{C}$ via the IHX which supplies high-temperature nuclear process heat directly to the system. The sweep gas then enters the electrolyzer, where it is combined with product oxygen. Finally, it passes through the electrolysis recuperator to help preheat the incoming process gas. Some of the sweep gas compression work is recovered using a sweep-gas turbine located at the sweep-gas exit.

The custom electrolyzer module developed at INL for direct incorporation into the UniSim system analysis code has been described in detail previously [2]. The electrolyzer model process flow diagram is shown in Figure 3. The process flow consisting of steam and hydrogen $(90 \%$ and $10 \%$ by volume) passes through a conversion reactor where the steam is split into hydrogen and oxygen. The conversion reactor model uses a stoichiometric equation for the splitting of water. Based upon the utilization, a specified percentage of the steam is converted. UniSim calculates the heat of reaction for this conversion, which is shown as the "Electrolysis Heating" energy stream in Figure 3. The Liquid Product stream has no flow and is really a null stream. The hydrogen, oxygen, and steam enter a component splitter labeled Electrodes. The oxygen is split from the other components and exits at anode stream. The sweep gas mixes with the anode stream and exits as the Sweep/Gas $\mathrm{O}_{2}$ Out stream. An embedded spreadsheet is used to calculate the Nernst potential, operating voltage, current and electrolysis power. In this reference case, since the boundary conditions are isothermal, the heat into the electrolysis process is also calculated.

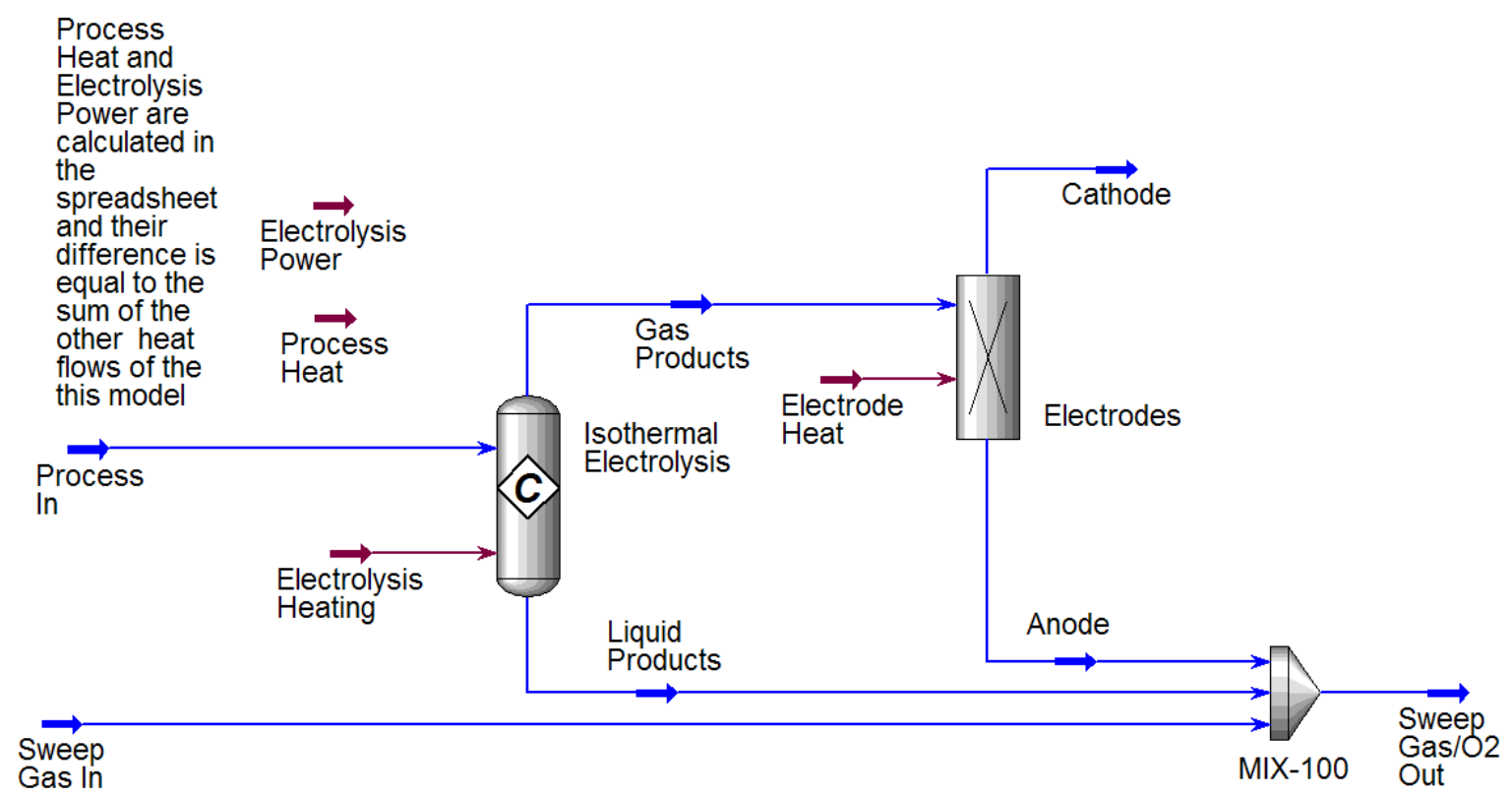

Figure 3. Process flow diagram of electrolyzer model. 


\section{Reference Design Conditions}

The H2A economic analysis methodology requires detailed information on plant design and performance in order to calculate lifecycle cost. Therefore, this section provides basic information on stream conditions and component design and performance information that are used as the basis for input to the H2A lifecycle cost analysis.

Fluid conditions, flow rates, stream composition and component operating parameters for the optimized reference case are summarized in Table 1 through Table 7 at each of the locations shown in Figure 2. The temperature, pressure, molar and mass flow rates, and the vapor fraction for each stream are displayed in Table 1. The composition of each stream is shown in Table 2. Table 3 provides the heat rates and the electrolysis power shown in Figure 2. The thermal duty, overall heat transfer coefficient, UA, log-mean temperature difference, LMTD, and the minimum approach temperature for each heat exchanger is found in Table 4. Turbine, compressor and pump parameters are given in Table 5 through Table 7. 
Table 1. Stream fluid conditions and flow rates for reference plant design.

\begin{tabular}{|c|c|c|c|c|c|}
\hline Name & $\begin{array}{l}\text { Vapor } \\
\text { Fraction }\end{array}$ & $\begin{array}{l}\text { Temperature } \\
\text { (C) }\end{array}$ & $\begin{array}{l}\text { Pressure } \\
\text { (MPa) }\end{array}$ & $\begin{array}{c}\text { Molar Flow } \\
\text { (gmole/s) }\end{array}$ & $\begin{array}{l}\text { Mass Flow } \\
(\mathrm{kg} / \mathrm{s})\end{array}$ \\
\hline Process In & 1 & 800 & 5 & 1461 & 23.98 \\
\hline Sweep Gas In & 1 & 800 & 5 & 1007 & 29.07 \\
\hline Sweep Gas/O2 Out & 1 & 800 & 5 & 1592 & 47.76 \\
\hline Cathode & 1 & 800 & 5 & 1461 & 5.282 \\
\hline 2 & 1 & 532.41 & 6.949 & $1.07 \mathrm{E}+04$ & 42.92 \\
\hline 3 & 1 & 539.85 & 7.07 & $1.07 E+04$ & 42.92 \\
\hline 4 & 1 & 540 & 7.07 & $8.01 \mathrm{E}+04$ & 320.5 \\
\hline 5 & 1 & 900 & 7.019 & $8.01 \mathrm{E}+04$ & 320.5 \\
\hline 6 & 1 & 900 & 7.019 & $6.94 \mathrm{E}+04$ & 277.6 \\
\hline 7 & 1 & 560.51 & 2.763 & $6.94 \mathrm{E}+04$ & 277.6 \\
\hline 8 & 1 & 540.02 & 7.07 & $6.94 \mathrm{E}+04$ & 277.6 \\
\hline 9 & 1 & 100.10 & 7.18 & $6.94 \mathrm{E}+04$ & 277.6 \\
\hline 10 & 1 & 120.10 & 2.713 & $6.94 \mathrm{E}+04$ & 277.6 \\
\hline 11 & 1 & 900 & 7.019 & 1.07E+04 & 42.92 \\
\hline 12 & 1 & 26 & 4.387 & $6.94 \mathrm{E}+04$ & 277.6 \\
\hline 13 & 1 & 100.03 & 4.407 & $6.94 \mathrm{E}+04$ & 277.6 \\
\hline 14 & 1 & 26 & 2.693 & $6.94 \mathrm{E}+04$ & 277.6 \\
\hline 15 & 1 & 170.57 & 5.035 & 1007 & 29.07 \\
\hline 16 & 1 & 46.85 & 2.034 & 1007 & 29.07 \\
\hline 17 & 1 & 176.85 & 2.054 & 1007 & 29.07 \\
\hline 18 & 1 & 46.85 & 0.7962 & 1007 & 29.07 \\
\hline 19 & 1 & 176.85 & 0.8047 & 1007 & 29.07 \\
\hline 20 & 1 & 46.85 & 0.3117 & 1007 & 29.07 \\
\hline 21 & 1 & 176.85 & 0.3147 & 1007 & 29.07 \\
\hline Air In & 1 & 26.85 & 0.1013 & 1007 & 29.07 \\
\hline 22 & 1 & 317.96 & 5.035 & 1461 & 23.98 \\
\hline 25 & 1 & 344.33 & 5.035 & 1315 & 23.68 \\
\hline 30 & 0 & 17.07 & 5.07 & 1315 & 23.68 \\
\hline 32 & 0 & 15.97 & 5.07 & 1170 & 21.07 \\
\hline Water In & 0 & 15.56 & 0.1013 & 1170 & 21.07 \\
\hline 31 & 0.9102 & 80.34 & 4.965 & 1461 & 5.282 \\
\hline 33 & 1 & 148.1 & 4.965 & 1592 & 47.76 \\
\hline 34 & 1 & -66.04 & 0.1013 & 1592 & 47.76 \\
\hline 36 & 1 & 26 & 4.965 & 146.2 & 0.2967 \\
\hline 37 & 1 & 27.64 & 5.035 & 146.2 & 0.2967 \\
\hline 38 & 0 & 26 & 4.965 & 145 & 2.612 \\
\hline Hydrogen Product & 1 & 26 & 4.965 & 1170 & 2.374 \\
\hline 40 & 0 & 26.01 & 5.07 & 145 & 2.612 \\
\hline 41 & 0 & 26.01 & 5.07 & 145.1 & 2.613 \\
\hline 35 & 1 & 26 & 4.965 & 1316 & 2.67 \\
\hline 24 & 1 & 27.64 & 5.035 & 146.2 & 0.2967 \\
\hline 1 & 1 & 532.41 & 6.949 & 6412 & 25.67 \\
\hline 23 & 1 & 900 & 7.019 & 4310 & 17.25 \\
\hline 26 & 1 & 900 & 7.019 & 6412 & 25.67 \\
\hline 27 & 1 & 532.41 & 6.949 & 4310 & 17.25 \\
\hline
\end{tabular}


Table 2. Mole fraction composition data for reference plant design.

\begin{tabular}{|c|c|c|c|c|c|}
\hline Name & Water & Hydrogen & Oxygen & Nitrogen & Helium \\
\hline Process In & 0.9 & 0.1 & 0 & 0 & 0 \\
\hline Sweep Gas In & 0 & 0 & 0.21 & 0.79 & 0 \\
\hline Sweep Gas/O2 Out & 0 & 0 & 0.5 & 0.5 & 0 \\
\hline Cathode & 0.1 & 0.9 & 0 & 0 & 0 \\
\hline 2 & 0 & 0 & 0 & 0 & 1 \\
\hline 3 & 0 & 0 & 0 & 0 & 1 \\
\hline 4 & 0 & 0 & 0 & 0 & 1 \\
\hline 5 & 0 & 0 & 0 & 0 & 1 \\
\hline 6 & 0 & 0 & 0 & 0 & 1 \\
\hline 7 & 0 & 0 & 0 & 0 & 1 \\
\hline 8 & 0 & 0 & 0 & 0 & 1 \\
\hline 9 & 0 & 0 & 0 & 0 & 1 \\
\hline 10 & 0 & 0 & 0 & 0 & 1 \\
\hline 11 & 0 & 0 & 0 & 0 & 1 \\
\hline 12 & 0 & 0 & 0 & 0 & 1 \\
\hline 13 & 0 & 0 & 0 & 0 & 1 \\
\hline 14 & 0 & 0 & 0 & 0 & 1 \\
\hline 15 & 0 & 0 & 0.21 & 0.79 & 0 \\
\hline 16 & 0 & 0 & 0.21 & 0.79 & 0 \\
\hline 17 & 0 & 0 & 0.21 & 0.79 & 0 \\
\hline 18 & 0 & 0 & 0.21 & 0.79 & 0 \\
\hline 19 & 0 & 0 & 0.21 & 0.79 & 0 \\
\hline 20 & 0 & 0 & 0.21 & 0.79 & 0 \\
\hline 21 & 0 & 0 & 0.21 & 0.79 & 0 \\
\hline Air In & 0 & 0 & 0.21 & 0.79 & 0 \\
\hline 22 & 0.9 & 0.1 & 0 & 0 & 0 \\
\hline 25 & 1 & 0 & 0 & 0 & 0 \\
\hline 30 & 1 & 0 & 0 & 0 & 0 \\
\hline 32 & 1 & 0 & 0 & 0 & 0 \\
\hline Water In & 1 & 0 & 0 & 0 & 0 \\
\hline 31 & 0.1 & 0.9 & 0 & 0 & 0 \\
\hline 33 & 0 & 0 & 0.5 & 0.5 & 0 \\
\hline 34 & 0 & 0 & 0.5 & 0.5 & 0 \\
\hline 36 & 0.0008 & 0.9992 & 0 & 0 & 0 \\
\hline 37 & 0.0008 & 0.9992 & 0 & 0 & 0 \\
\hline 38 & 0.9999 & 0.0001 & 0 & 0 & 0 \\
\hline Hydrogen Product & 0.0008 & 0.9992 & 0 & 0 & 0 \\
\hline 40 & 0.9999 & 0.0001 & 0 & 0 & 0 \\
\hline 41 & 0.9999 & 0.0001 & 0 & 0 & 0 \\
\hline 35 & 0.0008 & 0.9992 & 0 & 0 & 0 \\
\hline 24 & 0.0008 & 0.9992 & 0 & 0 & 0 \\
\hline 1 & 0 & 0 & 0 & 0 & 1 \\
\hline 23 & 0 & 0 & 0 & 0 & 1 \\
\hline 26 & 0 & 0 & 0 & 0 & 1 \\
\hline 27 & 0 & 0 & 0 & 0 & 1 \\
\hline
\end{tabular}


Table 3. Component heat rates and electrolysis power for reference design.

\begin{tabular}{lcc}
\multicolumn{1}{c}{ Name } & Heat Flow (kW) \\
Process Heat & $3.298 \mathrm{E}+04$ \\
\hline Reactor Heat & $6.000 \mathrm{E}+05$ \\
Intercooler Q & $1.071 \mathrm{E}+05$ \\
Precooler Q & $1.360 \mathrm{E}+05$ \\
AC 3 Q & 3970 \\
\hline AC 2 Q & 3921 \\
\hline AC 1 Q & 3901 \\
Ambient Cooling & -3237 \\
Electrolysis Power & $-2.578 \mathrm{E}+05$
\end{tabular}

Table 4. Heat exchanger design parameters for reference plant design.

\begin{tabular}{lccccc}
\multicolumn{1}{c}{ Name } & $\begin{array}{c}\text { Duty } \\
\text { (kW) }\end{array}$ & $\begin{array}{c}\text { UA } \\
\text { (W/C) }\end{array}$ & $\begin{array}{c}\text { LMTD } \\
(\mathbf{C})\end{array}$ & $\begin{array}{c}\text { Minimum Approach } \\
\text { (C) }\end{array}$ \\
\cline { 2 - 6 } Recuperator & $6.357 \mathrm{E}+05$ & $3.13 \mathrm{E}+07$ & 20.29 & 20 \\
Intermediate Heat Exchanger & $4.906 \mathrm{E}+04$ & $2.907 \mathrm{E}+05$ & 168.8 & 100 \\
Electrolysis Heat Recuperator & $7.141 \mathrm{E}+04$ & $6.132 \mathrm{E}+05$ & 116.4 & 50
\end{tabular}

Table 5. Turbine design parameters for reference plant design.

\begin{tabular}{|c|c|c|c|}
\hline Name & $\begin{array}{l}\text { Adiabatic } \\
\text { Efficiency }\end{array}$ & Polytropic Efficiency & Power (kW) \\
\hline Turbine & 93 & 92 & $4.905 E+05$ \\
\hline Sweep Gas Turbine & 75 & 62 & 9714 \\
\hline
\end{tabular}

Table 6. Compressor design parameters for reference plant design.

\begin{tabular}{lcc}
\hline \multicolumn{1}{c}{ Name } & Adiabatic Efficiency & Power (kW) \\
\cline { 1 - 3 } $\begin{array}{l}\text { Primary Circulator } \\
\text { High Pressure } \\
\text { Compressor }\end{array}$ & 75 & 1664 \\
Low Pressure & 88 & $1.071 \mathrm{E}+05$ \\
Compressor & & \\
\hline Air Cmp 4 & 88 & $1.069 \mathrm{E}+05$ \\
Air Cmp 3 & 75 & 3699 \\
Air Cmp 2 & 75 & 3886 \\
Air Cmp 1 & 75 & 3887 \\
Recirc & 75 & 4476 \\
& 75 & 6.924
\end{tabular}

Table 7. Pump design parameters for reference plant design.

\begin{tabular}{|lccc|}
\multicolumn{1}{c}{ Name } & $\begin{array}{c}\text { Adiabatic } \\
\text { Efficiency (\%) }\end{array}$ & Power (kW) & Pressure Head (m) \\
\hline Water Pump & 75 & 137.6 & 499.5 \\
\hline Water Recycle Pump & 75 & 0.3628 & 10.62
\end{tabular}




\section{Economic Analysis}

The economic analysis of the reference plant design was performed using the H2A analysis methodology developed by the Department of Energy (DOE) Hydrogen Program. H2A, which stands for hydrogen analysis, was initiated in February 2003 to improve the transparency and consistency of the approach to analysis, to improve the understanding of the differences among analyses, and to seek better validation of analysis studies by industry. The objectives of $\mathrm{H} 2 \mathrm{~A}$ as defined in Reference [7] are to:

1. Establish a standard format and list of parameters for reporting analysis results for central production, distributed (forecourt) production, and delivery.

2. Seek better validation of public analyses through dialog with industry.

3. Enhance understanding of the differences among publicly available analyses and make these differences more transparent.

4. Establish a mechanism for facile dissemination of public analysis results.

5. Work to reach consensus on specific analysis parameters for production and delivery.

The first task of the H2A effort was to develop a standardized approach and set of assumptions for estimating the lifecycle costs of hydrogen production and delivery technologies (and the resulting cost of hydrogen). Applying the same methodology to each technology and choosing appropriate assumptions will lead to an equitable comparison across technologies.

The standardized approach and set of assumptions for estimating the lifecycle cost of hydrogen production have been incorporated into a spreadsheet that was used for the economic analyses of the INL reference HTE design. This standardized spreadsheet provides a method of

documenting information utilized in the performance of the economic analyses. The information incorporated in the spreadsheet includes:

- Original source(s) of all the data (i.e., report title, authors, etc.)

- Basic process information (feedstock and energy inputs, size of plant, co-products produced, etc.)

- Process flowsheet and stream summary (flowrate, temperature, pressure, composition of each stream)

- Technology performance assumptions (e.g., process efficiency and hydrogen product conditions)

- Economic assumptions (after tax internal rate of return, depreciation schedule, plant lifetime, income tax rate, capacity factor, etc.)

- Calculation of the discounted cash flow (the calculation procedure is built into the standardized spreadsheet so that all technologies use the same methodology)

- Results (plant-gate hydrogen selling price and cost contributions in $\$ / \mathrm{kg} \mathrm{H} 2$, operating efficiency, total fuel and feedstock consumption, and emissions)

- Sensitivity of the results to assumptions (e.g., feedstock cost, co-product selling price, capital cost, operating costs, internal rate of return, conversion efficiencies, etc.)

- Quantification of the level of uncertainty in the analysis.

The results of technology lifecycle costing exercises depend on various financial assumptions. To facilitate a common basis for comparing alternative hydrogen production technologies, a 
standard set of assumptions were developed. These assumptions are delineated in the following section.

\subsection{Assumptions}

As part of the H2A economic analysis methodology, a set of common cost assumptions were developed and incorporated into the analysis spreadsheet. The common cost assumptions were intended to be applied for all H2A Central and Forecourt supply options, but analysts can vary these assumptions to test the sensitivity of costs to the most critical assumptions. The set of base case assumptions used in the H2A methodology are [7]:

- Analysis Methodology - Discounted Cash Flow (DCF) model that calculates a levelized $\mathrm{H} 2$ price that yields prescribed IRR

- Reference Financial Structure - 100\% equity with 10\% IRR - Include levelized H2 price plot for 0 to $25 \%$ IRR - Model allows debt financing

- Reference Year Dollars - 2005, to be adjusted at half-decade increments (e.g., 2005, 2010)

- Technology Development Stage - All Central and Forecourt cost estimates are based on mature, commercial facilities

- Inflation Rate - $1.9 \%$, but with resultant price of $\mathrm{H} 2$ in reference year constant dollars

- Income Taxes - 35\% Federal; 6\% State; 38.9\% Effective Property Taxes and Business Insurance - 2\%/year of the total initial capital cost

- Sales Tax - Not included on basis that facilities and related purchases are wholesale and through a general contractor entity

- Working Capital Rate - $15 \%$ of the annual change in the total operating costs

- Analysis Period - 40 years for Central; 20 years for Forecourt

- Facility Life - 40 years for Central with case exceptions; 20 years for Forecourt with case exceptions

- Depreciation Type and Schedule for Initial Depreciable Capital Cost - MACRS 20 years for Central with case exceptions; 7 years for Forecourt

- Construction Period and Cash Flow - Varies per case for Central; 0 for Forecourt

- Planned Replacement Capital - Post startup capital costs spread over time based on specific replacement estimates. Depreciation is based on MACRS schedule and 7 years or the same as the replacement period if it is shorter than 7 years.

- Unplanned Replacement Capital - Specified percentage of initial depreciable capital cost meant to handle unplanned replacement capital expenses that occur during an operating year of the plant. Depreciation is based on MACRS schedule and 7 years.

- Project Contingency - \% adjustment to the total initial capital cost such that the result represents the mean or expected cost value. Periodic replacement capital includes project contingency.

- Process Contingency — \% adjustment to the total initial capital cost such that the result incorporates the mean or expected overall performance.

- Land Cost — \$5000/acre purchased for Central; $\$ 0.5 /$ sqft/month for long-term lease for Forecourt

- Capacity Factor - 90\% for Central, with case exceptions; 70\% for Forecourt 
- Average Burdened Labor Rate for Staff - $\$ 50 /$ hour for Central; $\$ 15 /$ hour for Forecourt

- G\&A Rate - $20 \%$ of the staff labor costs above

- Forecourt Maintenance and Repair - 5\%/yr of initial depreciable capital cost for small capacity and 3\%/yr for large capacity

- Co-produced and Cogenerated Electricity Price — \$30/MWh with sensitivities based on $\$ 20 / \mathrm{MWh}$ low and \$50/MWh high

- $\mathrm{CO}_{2}$ incentive (when $\mathrm{CO}_{2}$ sequestration is not plausible) - not included in Base cases, sensitivity included at $\$ 100 /$ tonne $\mathrm{C}\left(\$ 27.3 /\right.$ tonne $\left.\mathrm{CO}_{2}\right)$ for Central and Forecourt.

- $\mathrm{O}_{2}$ Credit - Not included in Base cases, sensitivity included at $\$ 20 /$ tonne for Central and Forecourt.

- Salvage Value - 10\% of initial capital, with case exceptions; $0 \%$ for Forecourt

- Decommissioning - 10\% of initial capital, with case exceptions; $0 \%$ for Forecourt

- Hydrogen Pressure at Central Gate - 300 psig. If higher pressure is inherent to the process, apply pumping power credit for pressure $>300$ psig.

- Central Storage - Buffer only as required for efficient operations

- Hydrogen Storage Pressure at Forecourt - 6250 psig

- Forecourt Compressed $\mathrm{H}_{2}$ Storage - $87.5 \%$ of maximum daily production (based on $35 \%$ of production divided by an assumed $40 \%$ dispensable hydrogen fraction)

- Hydrogen Purity - 98\% minimum; CO $<10$ ppm, sulfur $<10$ ppm

- Sensitivity Variables and Ranges - Based on applying best judgment of $10 \%$ and $90 \%$ confidence limit extremes to the most significant baseline cost and performance parameters

The above assumptions along with basic process information calculated using the UniSim model shown in Figure 2 of Section 4 were input to the H2A spreadsheet to calculate the lifecycle cost for the MHR-driven hydrogen production process. The input to the spreadsheet and calculated lifecycle costs are described in more detail in the next two sections.

\subsection{Input to H2A Lifecycle Analysis}

Input for the H2A lifecycle cost analysis for the reference HTE design included plant performance and process information, financial data, and cost information (including capital, operating, maintenance, variable production, and replacement costs). As noted earlier, the plant performance and process information was obtained from the UniSim model of the reference HTE design described previously.

The financial information used in the spreadsheet was primarily based on the assumptions described in Section 6.1, but many of these values can also be changed by the user to perform sensitivities on the important financial assumptions. Plant-specific financial input by the user includes information like the construction time, plant startup date, plant design production capacity, plant operating capacity factor, capital expenditure rate during construction, and revenue and operating costs during startup. Table 8 and Table 9 show selected financial input values used in the analysis of the reference HTE plant design. Where appropriate, the basis and reference for the selected value used in the analysis is also included. Most of the financial input 
for Table 8 uses the recommended guidelines of the H2A methodology [8]. The start-up date is based on an assumed 2008 start date for construction of the reference plant design and an assumed 3 year construction period (GA-A25402). Construction costs were assumed to be evenly distributed over the 3 year construction period.

Table 8. Basic financial assumptions for reference HTE plant design.

\begin{tabular}{|c|c|c|c|}
\hline & Base Case & Comments & Data source \\
\hline Reference \$ Year & 2005 & H2A Guideline & \\
\hline Assumed Start-up Year & 2011 & $\begin{array}{l}\text { Based on } 2008 \\
\text { start of } \\
\text { construction }\end{array}$ & \\
\hline After-Tax Real IRR (\%) & $10 \%$ & H2A Guideline & \\
\hline Depreciation Type (MACRS, Straight Line) & MACRS & H2A Guideline & \\
\hline Depreciation Schedule Length (No. of Years) & 20 & H2A Guideline & \\
\hline Analysis Period (years) & 40 & H2A Guideline & \\
\hline Plant Life (years) & 40 & H2A Guideline & \\
\hline Assumed Inflation Rate (\%) & $1.90 \%$ & H2A Guideline & \\
\hline State Income Taxes (\%) & $6.0 \%$ & H2A Guideline & \\
\hline Federal Income Taxes (\%) & $35.0 \%$ & H2A Guideline & \\
\hline Effective Tax Rate (\%) & $38.9 \%$ & & \\
\hline $\begin{array}{r}\text { Design Capacity at } 100 \% \text { Capacity (kg of } \\
\text { H2/day) }\end{array}$ & $203,562.41$ & $\begin{array}{l}8545 \mathrm{~kg} / \mathrm{hr} \times 24 \\
\mathrm{hr} / \mathrm{day} \times 0.9926 \\
\text { (mass fraction } \\
\mathrm{H} 2 \text { ) }\end{array}$ & $\begin{array}{l}\text { UniSim model: } \\
\text { Isothermal } \\
\text { Crnt } 0.25 \text { ASR } \\
0.4 \text { full usage } \\
\text { rev } 2 . \text { usc }\end{array}$ \\
\hline Operating Capacity Factor (\%) & $90 \%$ & H2A Guideline & \\
\hline Plant Output (kg H2/day) & $183,206.17$ & & \\
\hline Plant Output (kg H2/year) & $66,870,251.03$ & & \\
\hline$\%$ Equity Financing & $100 \%$ & H2A Guideline & \\
\hline$\%$ Debt Financing & $0 \%$ & & \\
\hline
\end{tabular}

The 1 year startup period and the startup revenues and costs (fixed and variable) shown in Table 9 below are INL estimates. The plant salvage value and decommissioning costs are consistent with the assumptions of the $\mathrm{H} 2 \mathrm{~A}$ analysis methodology. 
Table 9. Start up and decommissioning assumptions for reference plant design.

\begin{tabular}{|r|c|c|c|}
\hline Start-up Time (years) & 1 & Estimate & INL \\
\hline \% of Revenues During Start-up (\%) & $35 \%$ & Estimate & INL \\
\hline \% of Variable Operating Costs During Start-up (\%) & $80 \%$ & Estimate & INL \\
\hline \% of Fixed Operating Costs During Start-up (\%) & $80 \%$ & Estimate & INL \\
\hline Salvage Value of Capital (\% of Total Capital Investment) & $10 \%$ & H2A Guideline & \\
\hline Decommissioning Costs (\% of Depreciable Costs) & $10 \%$ & H2A Guideline & \\
\hline
\end{tabular}

Plant capital cost information input by the user includes uninstalled and installed system and equipment costs, indirect depreciable capital costs (including site preparation, engineering and design, licensing and permitting, and associated contingencies), and non-depreciable capital costs (primarily the cost of the land for the plant site).

The capital cost information for the reference plant design is summarized in Table 10 and Table 11 , along with basis for the values used and references. Plant equipment costs summarized in Table 10 include equipment costs for both the nuclear island and the hydrogen production plant. As indicated in the table, the nuclear equipment costs are based on estimates developed by General Atomics in the referenced pre-conceptual design report [9]. For the nuclear equipment, an installation factor (the factor by which the uninstalled equipment costs are multiplied to arrive at the installed equipment cost) of 1.35 was used based on an interpretation of information in the General Atomics pre-conceptual design report. For the hydrogen production plant equipment, installation factors are based on the various equipment references [Ref. 9 - 12] defined in Table 10. The total installed cost of plant equipment obtained by summing the costs in Column 3 of Table 10 is $\$ 469,159,854$. This represents the total depreciable direct capital investment. 
Table 10. Capital cost of major equipment/systems.

\begin{tabular}{|c|c|c|c|c|}
\hline $\begin{array}{r}\text { Major } \\
\text { pieces/systems of } \\
\text { equipment }\end{array}$ & $\begin{array}{l}\text { Uninstalled } \\
\text { Costs }\end{array}$ & $\begin{array}{l}\text { Installed } \\
\text { Cost }\end{array}$ & Comments & Data Source \\
\hline $\begin{array}{l}\text { Reactor Structures and } \\
\text { Improvements }\end{array}$ & $35,600,000$ & $48,060,000$ & $\begin{array}{l}\text { Capital costs for the reactor system } \\
\text { based on HTE-MHR design costs. } \\
\text { HTE-MHR design assumed } 4 \mathrm{MHR} \\
\text { modules. Therefore, costs divided by } \\
4 \text { to represent HTE plant driven by one } \\
600 \mathrm{MW} \text { reactor. Uninstalled cost }= \\
\$ 142.4 \mathrm{M} / 4=\$ 35,600,000 \text {. Since } \\
\text { structures, building, electrical and } \\
\text { miscellaneous equipment that normally } \\
\text { appear in installed cost factor are } \\
\text { broken out separately, the installed } \\
\text { cost factor for the MHR only includes } \\
\text { labor (construction services, home } \\
\text { office engineering and services, field } \\
\text { office engineering and services) during } \\
\text { construction. Therefore, installed cost } \\
\text { factor }=1+\$ 316 \mathrm{M} / \$ 902.8 \mathrm{M}=1.35\end{array}$ & $\begin{array}{l}\text { Reference [9] } \\
\text { GA-A25402 April } \\
\text { 2006; HTE } \\
\text { Economic } \\
\text { Analysis.xmcd }\end{array}$ \\
\hline MHR Equipment & $129,475,000$ & $174,791,250$ & $\begin{array}{l}\text { Uninstalled cost }=\$ 517.9 \mathrm{M} / 4= \\
\$ 129,475,000 . \mathrm{F}=1.35\end{array}$ & $\begin{array}{l}\text { Reference [9] } \\
\text { GA-A25402 April } \\
2006\end{array}$ \\
\hline PCS Equipment & $27,775,000$ & $37,496,250$ & $\begin{array}{l}\text { Uninstalled cost }=\$ 111.1 \mathrm{M} / 4= \\
\$ 27,775,000 . \mathrm{F}=1.35\end{array}$ & $\begin{array}{l}\text { Reference [9] } \\
\text { GA-A25402 April } \\
2006\end{array}$ \\
\hline $\begin{array}{l}\text { MHR Electrical } \\
\text { Equipment/Miscellaneous } \\
\text { Plant Equipment }\end{array}$ & $24,075,000$ & $32,501,250$ & $\begin{array}{l}\text { Uninstalled Electrical Equipment cost }= \\
\$ 66.2 \mathrm{M} / 4=\$ 16,550,000 ; \text { Uninstalled } \\
\text { Miscellaneous Equipment cost }= \\
\$ 30.1 \mathrm{M} / 4=\$ 7,525,000 ; \text { total }= \\
\$ 24,075,000 . \mathrm{F}=1.35\end{array}$ & $\begin{array}{l}\text { Reference [9] } \\
\text { GA-A25402 April } \\
2006\end{array}$ \\
\hline $\begin{array}{l}\text { MHR Heat Rejection } \\
\text { System }\end{array}$ & $8,775,000$ & $11,846,250$ & $\begin{array}{l}\text { Uninstalled cost }=\$ 35.1 \mathrm{M} / 4= \\
\$ 8,775,000 . \mathrm{F}=1.35\end{array}$ & $\begin{array}{l}\text { Reference [9] } \\
\text { GA-A25402 April } \\
2006\end{array}$ \\
\hline $\begin{array}{l}\text { Primary Coolant } \\
\text { Circulator/HTRS Isolation } \\
\text { Valves/Helium Services } \\
\text { System }\end{array}$ & $6,725,000$ & $8,242,833$ & $\begin{array}{l}\text { Uninstalled primary coolant circ }= \\
\$ 17.6 \mathrm{M} / 4=\$ 4,400,000, \mathrm{~F}(\mathrm{GA})=1.2 \\
\text { for } \mathrm{HTE} \text { plant, Installed primary coolant } \\
\text { pump }=\$ 5,280,000--- \text { Uninstalled } \\
\mathrm{HTRS} \text { Isolation Valve }=\$ 4.7 \mathrm{M} / 4= \\
\$ 1,175,000 ; \mathrm{F}(\mathrm{GA})=1.2 \text { for HTE } \\
\text { plant; Installed HTRS }=\$ 1,410,000 . \text {--- } \\
\text { Uninstalled Primary Helium Services } \\
\text { system }=\$ 4.6 \mathrm{M} / 4=\$ 1,150,000 ; \mathrm{F}(\mathrm{GA}) \\
=1.35 \text { for nuclear plant; Installed } \\
\text { Primary Helium Services system }= \\
\$ 1,552,500 .--- \text { Total Uninstalled cost }= \\
\$ 6,725,000 ; \text { Total Installed cost }= \\
\mathrm{F}(\mathrm{GA})=1.20 \text { for HTE plant. Installed } \\
\text { cost }=\$ 8,242,500 ; \mathrm{F}(\text { composite })= \\
1.2257\end{array}$ & $\begin{array}{l}\text { Reference [9] } \\
\text { GA-A25402 April } \\
2006\end{array}$ \\
\hline $\mathrm{IHX}$ and Vessel & $10,300,000$ & $12,360,000$ & $\begin{array}{l}\text { Uninstalled cost }=(\$ 29.4 \mathrm{M}+\$ 11.8 \mathrm{M}) / 4 \\
=\$ 10,300,000 . \mathrm{F}=1 .+ \\
\$ 158 \mathrm{M} / \$ 790.2 \mathrm{M}=1.20 \text { for HTE plant } \\
(\mathrm{GA}) . \mathrm{F}=1.2 \text { for HTE plant }\end{array}$ & $\begin{array}{l}\text { Reference [9] } \\
\text { GA-A25402 April } \\
2006\end{array}$ \\
\hline
\end{tabular}




\begin{tabular}{|c|c|c|c|c|}
\hline $\begin{array}{l}\text { Water Separation Tank } \\
\text { and Water Recycle Pump }\end{array}$ & 81,390 & 385,789 & 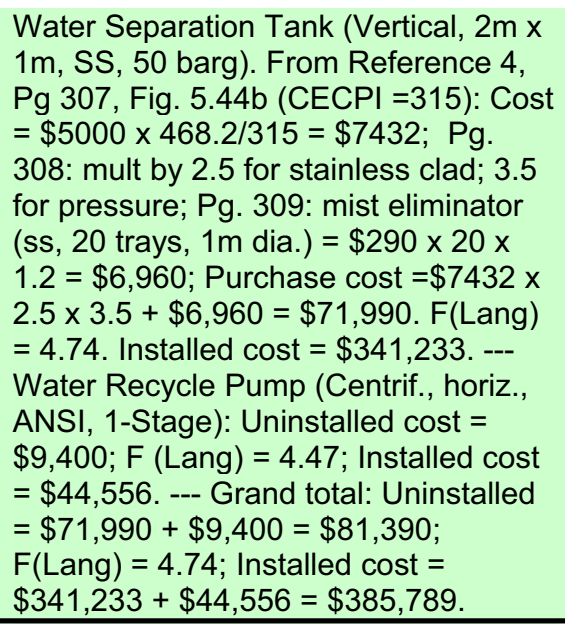 & $\begin{array}{l}\text { Water separation } \\
\text { tank: Reference } \\
\text { [10] --- Water } \\
\text { Recycle Pump: } \\
\text { Reference [11]. }\end{array}$ \\
\hline $\begin{array}{l}\text { Water Supply System and } \\
\text { Main Water Pump }\end{array}$ & $1,020,700$ & $1,298,126$ & $\begin{array}{l}\text { Water Supply System: Uninstalled cost } \\
=\$ 4 \mathrm{M} / 4=\$ 1,000,000 ; \mathrm{F}=1.2 ; \\
\text { Installed cost }=\$ 1,200,000 .-- \text { Main } \\
\text { Water Pump (Centrif., horiz., ANSI, } 1 \text { - } \\
\text { Stage, } 8 \text { in dia disch, SS-304, dbl } \\
\text { mech seal). Uninstalled cost }= \\
\$ 20,700 ; \mathrm{F}(\text { Lang) }=4.74 ; \text { Installed cost } \\
=\$ 98,118 \text {.-- Grand total: Uninstalled } \\
\text { cost }=\$ 1,000,000+\$ 20,700= \\
\$ 1,020,700 ; \text { Installed cost }= \\
\$ 1,200,000+\$ 98,118=\$ 1,298,118 ; \\
\mathrm{F}(\text { Composite })=1.2718 \text {. }\end{array}$ & $\begin{array}{l}\text { Water supply: } \\
\text { Reference [9] } \\
\text { GA-A25402 April } \\
2006 \text {--- Main } \\
\text { Water Pump: } \\
\text { Reference [11]. }\end{array}$ \\
\hline Air Compressors (four) & $10,938,691$ & $26,784,479$ & 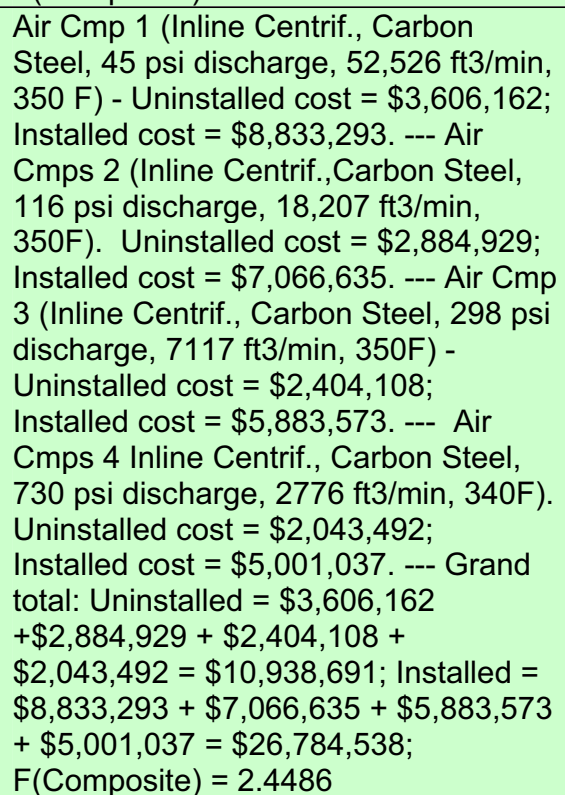 & $\begin{array}{l}\text { Reference [12]. } \\
\text { NETL_cost } \\
\text { estimate.xls }\end{array}$ \\
\hline Air Coolers (three) & 432,738 & $1,059,040$ & $\begin{array}{l}\text { Air coolers }(\mathrm{Q}=1.338 \mathrm{e} 7 \mathrm{Btu} / \mathrm{hr} \text {, delT }= \\
116 \mathrm{~F}, \mathrm{U}=25 \mathrm{Btu} / \mathrm{hr} / \mathrm{ft} 2 / \mathrm{F}(\mathrm{Kreith}, \mathrm{Pg} \\
463), \mathrm{A}=4614 \mathrm{ft} 2) .--- \text { Three Air } \\
\text { Coolers: Uninstalled cost }=\$ 144,246 \times 1 \\
3=\$ 432,738 ; \text { Installed Cost }= \\
\$ 353,014 \text { x } 3=\$ 1,059,042 ; \mathrm{F}= \\
2.4473 .\end{array}$ & $\begin{array}{l}\text { Reference [12]. } \\
\text { NETL_cost } \\
\text { estimate.xls }\end{array}$ \\
\hline
\end{tabular}




\begin{tabular}{|c|c|c|c|c|}
\hline $\begin{array}{l}\text { Electrolysis Heat } \\
\text { Recuperator/Electrolysis } \\
\text { Heater }\end{array}$ & $1,390,451$ & $6,590,738$ & 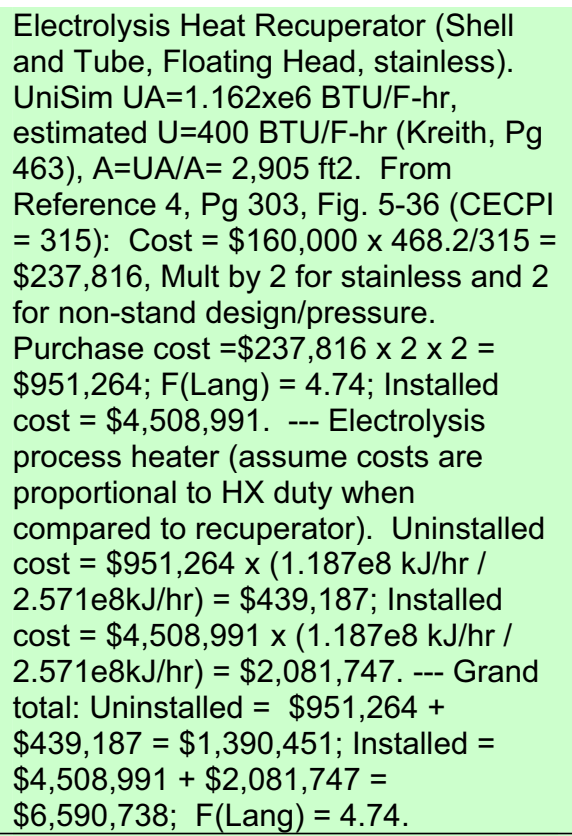 & Reference [10]. \\
\hline $\begin{array}{l}\text { Sweep Gas Turbine/H2 } \\
\text { Recirculator }\end{array}$ & $3,265,146$ & $8,035,851$ & $\begin{array}{l}\text { Sweep Gas Turbine }(13,030 \mathrm{hp}, 720 \\
\text { psi inlet, } 300 \mathrm{~F} \text { in). Uninstalled cost }= \\
\$ 3,245,546 ; \text { Installed cost }= \\
\$ 7,942,824 ; \mathrm{F}=2.4473 .---\mathrm{H} 2 \\
\text { Recirculator (Centrif., } 20 \mathrm{hp}, 1000 \\
\text { psi,CS). Uninstalled cost }=\$ 19,600 ; \\
\mathrm{F}(\text { Lang) }=4.74 ; \text { Installed cost }= \\
\$ 92,904 \text {--- Grand Total: Uninstalled = } \\
\$ 3,265,146 ; \text { Installed }=\$ 8,035,728 ; \\
\mathrm{F}(\text { Composite })=2.4611 .\end{array}$ & $\begin{array}{l}\text { Sweep Gas } \\
\text { Turbine: } \\
\text { Reference [12]. } \\
\text { NETL_cost } \\
\text { estimate.xls --- } \\
\text { H2 Recirculator: } \\
\text { Reference [11]. }\end{array}$ \\
\hline $\begin{array}{l}\text { HTE Piping, Electrical } \\
\text { Equipment (including } \\
\text { AC/DC conversion [5]), } \\
\text { Misc. HTE plant } \\
\text { Equipment }\end{array}$ & $5,750,000$ & $6,900,000$ & $\begin{array}{l}\text { Uninstalled costs. HTE piping }=\$ 5 \mathrm{M} / 4 \\
=\$ 1,250,000 . \text { Electrical Equipment }= \\
\$ 2,000,000 \text { (estimate). Misc. } \\
\text { Equipment }=\$ 10 \mathrm{M} / 4=\$ 2,500,000 . \mathrm{F} \\
(\mathrm{FTE} \text { plant }-\mathrm{GA})=1.2 .\end{array}$ & $\begin{array}{l}\text { Reference [9] } \\
\text { GA-A25402 April } \\
2006\end{array}$ \\
\hline $\begin{array}{l}\text { Solid Oxide Electrolyzer } \\
\text { (SOE) Modules }\end{array}$ & $51,560,000$ & $92,808,000$ & $\begin{array}{l}\text { Uninstalled Cost. } 257,800 \mathrm{kw} \\
x \$ 200 / \mathrm{kw} \mathrm{F}(\mathrm{INL})=1.8\end{array}$ & $\begin{array}{l}\text { INL/Cerametec } \\
\text { Estimate }\end{array}$ \\
\hline
\end{tabular}

The indirect depreciable capital costs (engineering and design, contingencies and licencing/permitting fees) are summarized in Table 11, along with the basis and reference for the values used. The total indirect depreciable capital costs, obtained by summing the costs in Column 2 of the table below, amount to $\$ 203,338,738$. Adding these costs to the direct depreciable costs from Table 10 above, gives a total depreciable capital cost for the reference HTE plant of $\$ 672,498,592$. 
Table 11. Indirect depreciable capital costs.

\begin{tabular}{|c|c|c|c|}
\hline & Base Case: & Comments: & Data source: \\
\hline Site preparation $(\$)$ & $1,000,000$ & INL estimate & \\
\hline Engineering \& design $(\$)$ & $70,373,978$ & $\begin{array}{l}\text { Assume 15\% } \\
\text { of capital } \\
\text { costs. }\end{array}$ & $\begin{array}{l}\text { Reference [10], Page } \\
275 \text { recommends } 15 \% \\
\text { of equipment and } \\
\text { installation costs. }\end{array}$ \\
\hline Process contingency $(\$)$ & $23,457,993$ & $\begin{array}{l}\text { Assume 5\% } \\
\text { of direct } \\
\text { costs. }\end{array}$ & \\
\hline Project contingency $(\$)$ & $93,831,971$ & $\begin{array}{l}\text { Assume } 20 \% \\
\text { of direct } \\
\text { costs. }\end{array}$ & $\begin{array}{l}\text { Reference [10], Page } \\
275-276 \text { recommends } \\
15 \% \text { contingency, but } \\
\text { use } 20 \% \text { for } \\
\text { conservatism. }\end{array}$ \\
\hline Other (\$) & 100,000 & INL estimate & \\
\hline One-time licensing fees $(\$)$ & $14,074,796$ & INL estimate & $\begin{array}{l}\text { Reference [10], Page } \\
275-276 \text { recommends } \\
3 \% \text { of equipment and } \\
\text { installation costs for } \\
\text { fees. }\end{array}$ \\
\hline Up-front permitting costs $(\$)$ & 500,000 & INL estimate & \\
\hline
\end{tabular}

The only non-depreciable cost assumed in the reference plant lifecycle analysis was the cost of land required for the plant site. The land required for the plant (including the exclusion area) was assumed to be 200 acres. At an assumed cost of $\$ 5000$ per acre (H2A guideline), the total non-depreciable land cost is $\$ 1,000,000$. Adding this cost to the total direct and indirect depreciable capital costs in Table 10 and Table 11 gives a total capital investment cost for the reference HTE plant of $\$ 673,498,592$.

Additional costs to be considered in the reference HTE plant lifecycle analysis are the operation and maintenance $(\mathrm{O} \& \mathrm{M})$ costs and variable production costs. The operations and maintenance costs include burdened labor and material costs, various plant permits, licenses, fees and taxes. These fixed O\&M costs are summarized in Table 12. 
Table 12. Fixed O\&M costs for reference plant design.

\begin{tabular}{|c|c|c|c|}
\hline $\begin{array}{r}\text { Total plant staff } \\
\text { (number of FTEs } \\
\text { employed by plant) }\end{array}$ & 155.00 & $\begin{array}{l}\text { INL estimate. A four plant GT-MHR } \\
\text { requires } 241 \text { people on site } \\
\text { supplemented by off site technical } \\
\text { support group. For MHR-HTE, assume } \\
100 \text { for reactor operations, } 30 \text { to support } \\
\text { HTE operations, and } 25 \text { full time off-site } \\
\text { technical support group. Grand total = } \\
155 \text { staff. }\end{array}$ & $\begin{array}{l}\text { Reference [9] } \\
\text { GA } 910720 \\
\text { Rev. } 1 \text { Pg. 9- } \\
\text { 9. }\end{array}$ \\
\hline $\begin{array}{r}\text { Burdened labor } \\
\text { cost, including } \\
\text { overhead }(\$ / \text { man- } \\
\mathrm{hr})\end{array}$ & 50.00 & & \\
\hline Labor cost, $\$ /$ year & $\$ 16,120,000$ & & \\
\hline $\begin{array}{r}\text { G\&A rate }(\% \text { of } \\
\text { labor cost) }\end{array}$ & $20 \%$ & & \\
\hline G\&A (\$/year) & $\$ 3,224,000$ & & \\
\hline $\begin{array}{r}\text { Property tax and } \\
\text { insurance rate (\% } \\
\text { of total initial capital } \\
\text { costs) }\end{array}$ & $2.0 \%$ & & \\
\hline $\begin{array}{r}\text { Property taxes and } \\
\text { insurance (\$/year) }\end{array}$ & $\$ 13,469,972$ & & \\
\hline $\begin{array}{l}\text { Licensing, permits, } \\
\text { and fees (\$/year) }\end{array}$ & 100,000 & INL estimate. & \\
\hline $\begin{array}{c}\text { Material costs for } \\
\text { maintenance and } \\
\text { repairs (\$/year) }\end{array}$ & $3,750,000$ & INL estimate. & \\
\hline $\begin{array}{r}\text { TOTAL FIXED } \\
\text { O\&M COSTS } \\
\text { (\$/year, year } 2005 \\
\text { basis), excluding } \\
\text { materials }\end{array}$ & $\$ 36,827,633$ & & \\
\hline
\end{tabular}

The total fixed O\&M costs, obtained by summing the costs in Column 2 of the table above, amount to $\$ 36,827,633$. In addition to the fixed O\&M costs summarized in Table 12, there are variable production costs to be considered. These variable production costs include the cost of the nuclear fuel $(\$ 17,800,000$ per year) and demineralized water $(\$ 790,888)$ that provides the 
feedstock for the electrolysis process. The demineralized water cost was obtained by multiplying the required yearly demineralized water feedstock (obtained from UniSim) by the H2A assumed demineralized water cost of $\$ 0.00132 / \mathrm{L}$. Adding these variable costs to the fixed O\&M costs in Table 12 give a total fixed and variable yearly O\&M cost of \$55,418,521.

The only remaining costs to be considered in the reference HTE plant lifecycle analysis are the planned and unplanned yearly replacement costs. The planned replacement costs are the yearly cost of replacement of $1 / 3$ of the Solid Oxide Electrolyzer (SOE) modules, which amounts to $\$ 17,186,667 / y r$. In the lifecycle analysis, unplanned replacement costs were assumed to be $2.0 \%$ of total depreciable costs per year, and amount to $\$ 13,449,972$.

The financial and cost information described above provided the input for the H2A lifecycle spreadsheet analysis of the reference HTE hydrogen production plan. For convenience, Table 13 and Table 14 below summarize the capital investment and operational cost information developed for the reference HTE plant.

Table 13. Summary of capital investment costs (FY2005 \$).

\begin{tabular}{|c|c|}
\hline Capital Cost Items & Cost, $\mathbf{S}$ \\
\hline Direct depreciable costs (equipment and systems) & $469,159,854$ \\
\hline Indirect depreciable costs (site prep., engineering, permitting) & $203,338,738$ \\
\hline Total direct and indirect depreciable cost & $\mathbf{6 7 2 , 4 9 8 , 5 9 2}$ \\
\hline Non-depreciable cost (land) & $1,000,000$ \\
\hline Total capital investment cost & $\mathbf{6 7 3 , 4 9 8 , 5 9 2}$ \\
\hline
\end{tabular}

Table 14. Summary of operating costs (FY $2005 \$$ ).

\begin{tabular}{|l|l|}
\hline \multicolumn{1}{|c|}{ O\&M, Variable and Replacement Cost Items } & Cost, \$/yr. \\
\hline Fixed O\&M costs (staff, taxes, permitting) & $36,827,633$ \\
\hline Variable production costs (nuclear fuel and feedwater stock) & $18,590,888$ \\
\hline Replacement costs (SOE modules and unplanned replacements) & $30,636,639$ \\
\hline Total yearly costs & $\mathbf{8 6 , 0 5 5 , 1 6 0}$ \\
\hline
\end{tabular}

The results of the H2A spreadsheet analysis using the above cost and financial information are discussed in the following section.

\subsection{Results of H2A Lifecycle Analysis}

The results of the H2A lifecycle cost analysis include a cash flow analysis for the plant construction and startup periods, and for the operating life of the plant. The required hydrogen cost (price) in 2005 dollars is also determined based on the plant hydrogen-production capacity 
and assuming an after-tax internal rate of return (IRR) of $10 \%$. A critical assumption in this analysis is the assumed reactor outlet temperature that provides process heat and electricity to the electrolysis process. While a reactor outlet temperature of $950^{\circ} \mathrm{C}$ will provide a higher overall hydrogen production efficiency and lower hydrogen production costs, a reactor temperature of $900^{\circ} \mathrm{C}$ was chosen for the reference HTE plant design because it was felt the lower temperature is more consistent with the operating temperature range of currently available materials and components. As noted earlier, a $900^{\circ} \mathrm{C}$ reactor outlet temperature still results in a respectable $47.12 \%$ overall hydrogen production efficiency.

To achieve an after tax internal rate of return of $10 \%$ the required hydrogen price calculated using the H2A spreadsheet methodology is $\$ 3.23 / \mathrm{kg}$. This represents the price or cost of the hydrogen leaving the plant gate at $5 \mathrm{MPa}$ pressure, and does not include any additional storage, delivery, fuel taxes or other costs that the consumer might pay at the pump. The breakdown of these costs showing the different cost contributions is shown in Table 15.

Table 15. Hydrogen cost and cost contributions (year 2005 \$)

\begin{tabular}{|c|c|}
\hline Required Hydrogen Cost (Year $2005 \$) / \mathrm{kg}$ of H2) & $\$ 3.229$ \\
\hline Capital Cost Contribution $(\$ / \mathrm{kg}$ of H2) & $\$ 2.364$ \\
\hline Decommissioning Cost Contribution (\$/kg of H2) & $\$ 0.002$ \\
\hline Fixed O\&M Cost Contribution $(\$ / \mathrm{kg}$ of $\mathrm{H} 2)$ & $\$ 0.573$ \\
\hline Feedstock Cost Contribution $(\$ / \mathrm{kg}$ of $\mathrm{H} 2)$ & $\$ 0.012$ \\
\hline Other Raw Material Cost Contribution (\$/kg of H2) & $\$ 0.000$ \\
\hline Byproduct Credit Cost Contribution (\$/kg of H2) & $\$ 0.000$ \\
\hline $\begin{array}{r}\text { Other Variable Costs (including utilities) Contribution } \\
(\$ / \mathrm{kg} \text { of } \mathrm{H} 2)\end{array}$ & $\$ 0.278$ \\
\hline Total O\&M $(\$ / \mathrm{kg}$ of H2) & $\$ 0.863$ \\
\hline
\end{tabular}

As expected, capital costs $(\$ 2.36 / \mathrm{kg}$ of hydrogen) represent the largest contribution to the total hydrogen cost because of the high construction costs for the nuclear reactor. In this case, nuclear plant capital costs represent about $70 \%$ of the total capital cost, or approximately $\$ 1.65 / \mathrm{kg}$ of hydrogen. Fixed operating and maintenance costs $(\$ 0.57 / \mathrm{kg}$ of hydrogen) are relatively high because they include operation and maintenance costs for both the reactor and hydrogen production plant. The contributors to variable costs $(\$ 0.28 / \mathrm{kg}$ of hydrogen) include the reactor fuel cost, a reserve for unplanned equipment replacement costs, and the replacement cost of the SOE cells. The cost of the SOE modules was estimated to be $\$ 200 / \mathrm{kW}$ of power to the electrolysis stack and, as noted earlier, it is assumed that $1 / 3$ of the modules are replaced each year. The unplanned replacement costs were assumed to be $2 \%$ of the total direct depreciation costs per year. Since the reactor power source provided both electricity and process heat to drive the hydrogen production process, there are no utility or raw material cost contributions to the total hydrogen production cost. The feedstock cost contribution $(\$ 0.012 / \mathrm{kg}$ of hydrogen) represents the cost of the demineralized water feedstock, which feeds the electrolysis process. Although the electrolysis process also produces oxygen, which could be sold as a byproduct of the hydrogen production process, the reference HTE design does not attempt to recover the oxygen byproduct. Therefore, while the sale of the oxygen byproduct would lower the overall 
cost of the hydrogen production process by about $\$ 0.17 / \mathrm{kg}$, no credit for the production of oxygen was taken in this cost analysis.

Figure 4 is a plot of the calculated cash flow for the reference HTE design for a calculated design hydrogen production rate of $2.356 \mathrm{~kg} / \mathrm{s}$, an operating capacity factor of $90 \%$, and an operating life of 40 years. The equivalent yearly hydrogen production rate for the plant for these conditions is $66,870,251 \mathrm{~kg} / \mathrm{yr}$.

\section{Cumulative Cash Flow}

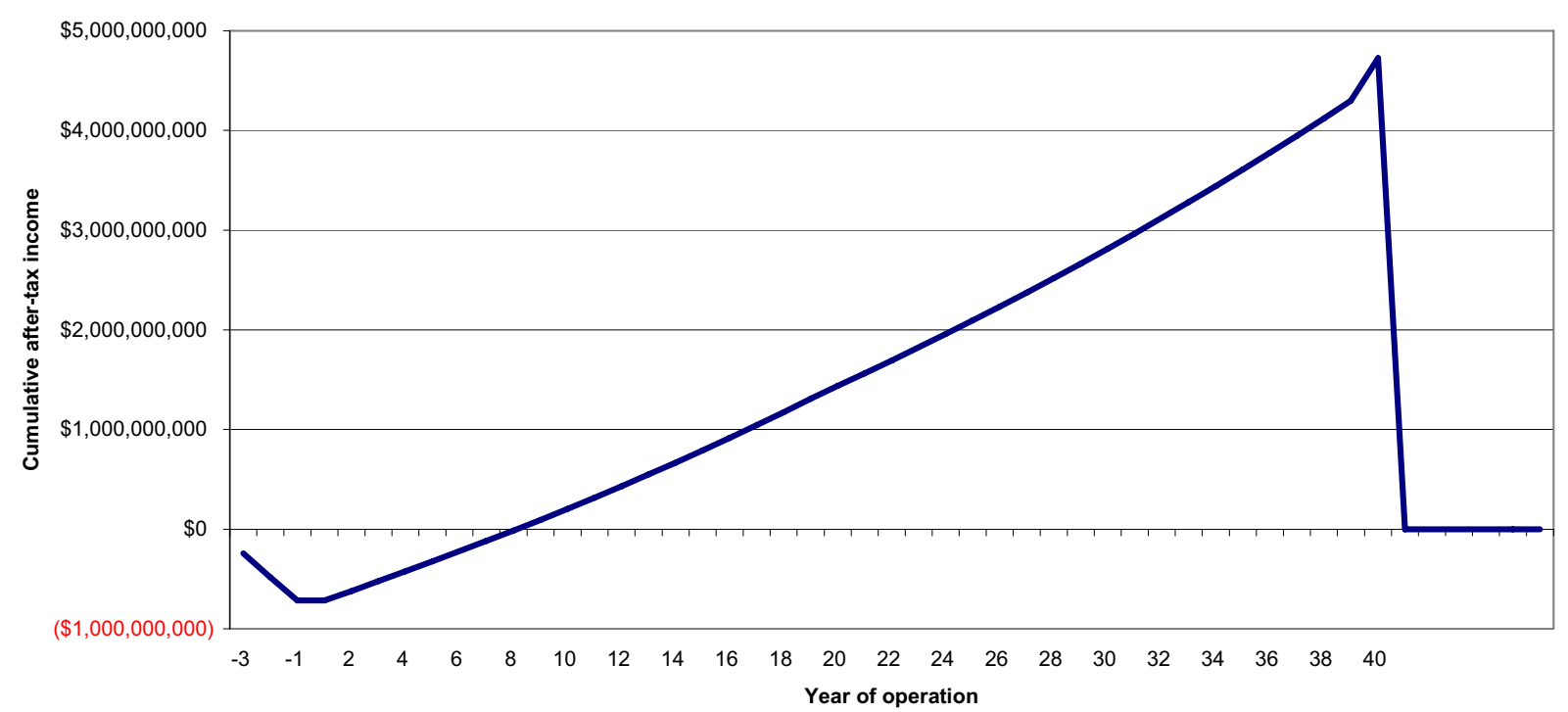

Figure 4. Cummulative cash flow for reference HTE plant.

Figure 4 shows that the initial capital investment is recovered in approximately 8 years after the start of construction and the cumulative after-tax income over the life of the plant of slightly less than $\$ 5$ billion.

\subsection{Sensitivity Studies}

Several sensitivity analyses were performed to evaluate the impact of various economic assumptions on hydrogen lifecycle production costs. The assumed after-tax internal rate of return was found to have a significant impact on cost of hydrogen production. Figure 5 shows that a variation of the internal rate of return between $0 \%$ and $25 \%$ results in hydrogen production cost variations between $\$ 1.64 / \mathrm{kg} \mathrm{H}_{2}$ and $\$ 7.40 / \mathrm{kg} \mathrm{H}_{2}$, respectively. 


\section{Hydrogen $\$ / k g$}

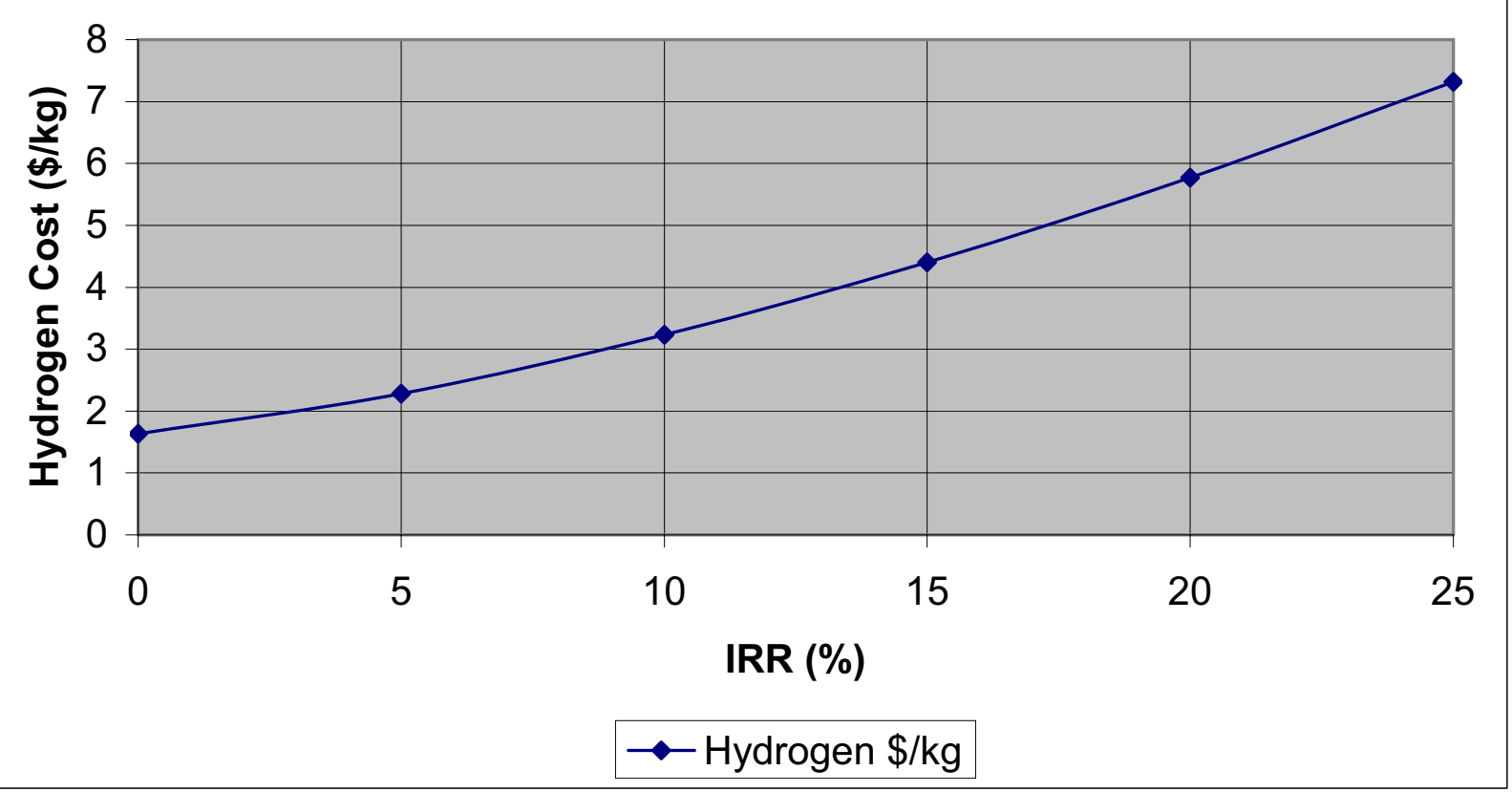

Figure 5. Calculated hydrogen production cost as a function of internal rate of return.

Figure 6 is a tornado plot that shows the sensitivity of hydrogen production costs to the various economic and operational assumptions used in the H2A economic analysis of the reference HTE plant. The tornado plot shows the impact on hydrogen production cost when a single variable is changed while holding other variables constant. In the tornado plot, the parameters that have the largest impact on production costs are shown at the top, and the parameters that have the least impact on hydrogen production costs are shown at the bottom. Therefore, the importance of parameters on hydrogen production costs decreases as the plot is read from top to bottom. As indicated in the plot, the after-tax internal rate of return has the greatest impact on hydrogen production costs. Unplanned replacement costs are next in importance. In this analysis, unplanned replacement costs were assumed to be $2 \%$ of the total direct depreciation costs per year. When the unplanned replacement costs are varied between $0 \%$ and $10 \%$, the resulting hydrogen production costs are $\$ 2.94 / \mathrm{kg}$ and $\$ 4.39 / \mathrm{kg}$, respectively. The third most important parameter in the cost analyses is the assumed cost of the SOE modules. In this analysis, the cost of the SOE modules was assumed to be $\$ 200$ per $\mathrm{kW}$ of electricity to the electrolysis stack. If this cost is varied between $\$ 100$ and $\$ 300$ per $\mathrm{kW}$, the cost of hydrogen varies between $\$ 2.83 / \mathrm{kg}$ and $\$ 3.63 / \mathrm{kg}$, respectively. Variations in the size of the plant staff, the cost of major reactor system components and the frequency at which the SOE cells are changed out all appear to have moderate affects on the cost of hydrogen production. Variations in engineering design costs seem to have only a small impact on hydrogen production cost. And, because the cost of the hydrogen plant equipment (turbomachinery, heat exchangers, piping, etc.) is low compared to the cost of the nuclear plant equipment and the SOE modules, the impact of variations in major hydrogen plant equipment costs has the least impact on hydrogen production costs of the parameters considered. 


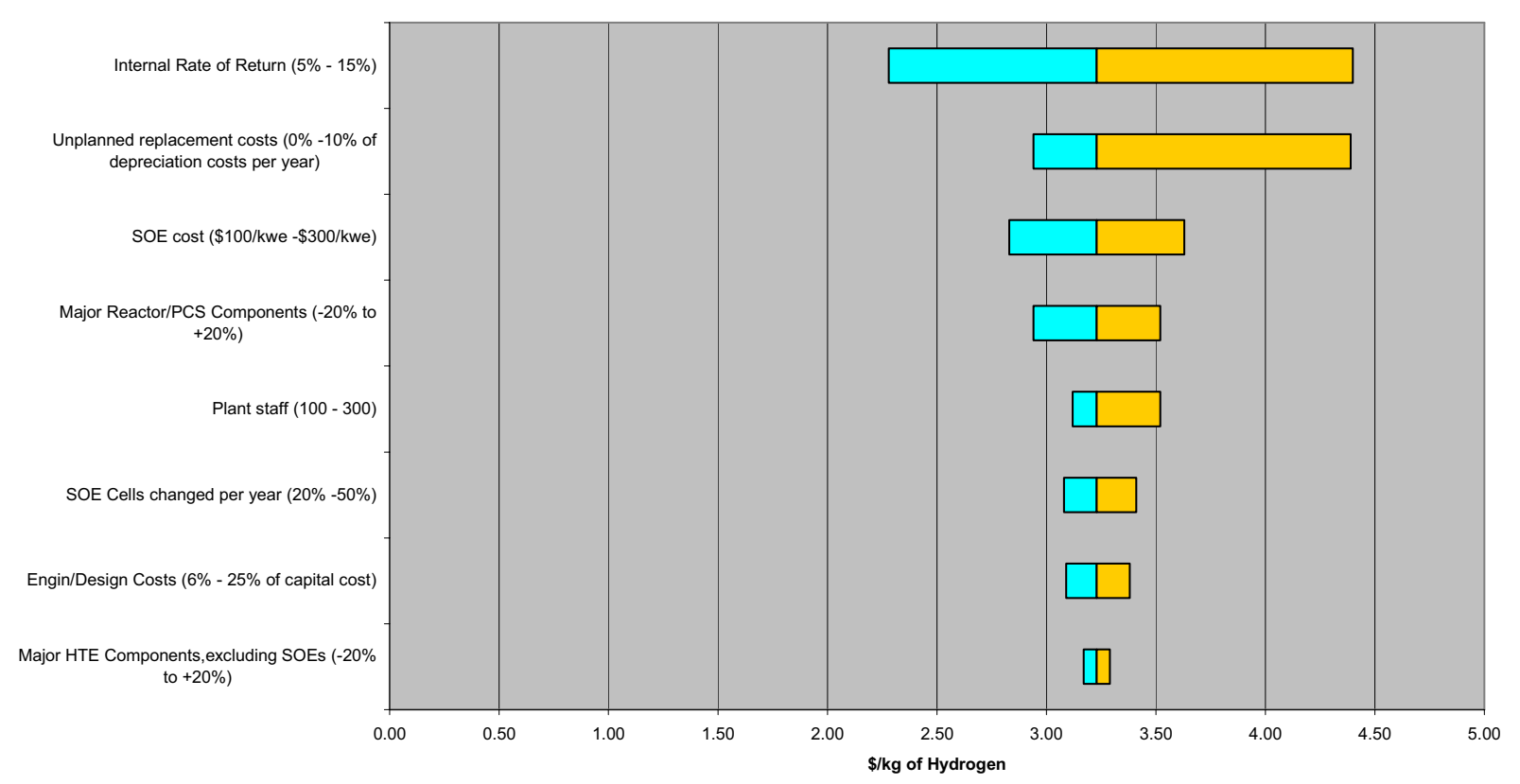

Figure 6. Tornado plot showing sensitivity of hydrogen cost to parameter variations. 


\section{Conclusions}

This report presents results of a lifecycle cost analysis of the optimized design for a reference commercial-scale high-temperature electrolysis (HTE) plant for hydrogen production. The reference HTE plant is driven by a $600 \mathrm{MWt}$ high-temperature helium-cooled reactor coupled to a direct Brayton power cycle with a reactor outlet temperature of $900^{\circ} \mathrm{C}$. While a reactor outlet temperature of $950^{\circ} \mathrm{C}$ will provide a higher overall hydrogen production efficiency and lower hydrogen production costs, a reactor temperature of $900^{\circ} \mathrm{C}$ was chosen for the reference HTE plant design because it was felt the lower reactor outlet temperature is more consistent with the operating temperature range of currently available materials and components. Other plant parameters used in the reference plant optimization are based on previous parametric studies performed using the UniSim process analysis software [3, 4].

The reference plant simulation was performed for a cell area-specific resistance value of 0.4 $\mathrm{Ohm} \cdot \mathrm{cm}^{2}$. The $A S R$ value of 0.4 [6] represents a stack-average ASR value that should be achievable in the short term with existing technology. Isothermal operation of the electrolyzer was assumed. An air sweep system is also included in the reference design to remove oxygen from the anode side of the electrolyzer because of concerns with handling of the hightemperature oxygen product gas. Predicted overall thermal-to-hydrogen efficiency values for the reference design with an air-sweep system resulted in hydrogen production efficiencies that were only $1.0-1.5$ percentage points lower than the equivalent design with no sweep-gas system [3]. The operating pressure of 5.0 MPa for the HTE process loop was selected to be consistent with the need to deliver the hydrogen product gas at elevated pressures for storage or pipeline transport. This pressure also represents a trade off between the need for larger components at lower pressures and the need for more massive components for pressure containment at higher pressures. The overall thermal-to-hydrogen efficiency for the reference case is $47.12 \%$.

The lifecycle cost analysis of the reference HTE design resulted in a calculated hydrogen cost of $\$ 3.26 / \mathrm{kg}$, assuming an after-tax internal rate of return of $10 \%$. This represents the cost of hydrogen leaving the plant gate, and does not include any additional storage, delivery, fuel taxes or other costs that the consumer might pay at the pump. A breakdown of the component costs contributing to the total cost of $\$ 3.23 / \mathrm{kg}$ shows that capital costs account for over $70 \%$ of total costs (i.e., $\$ 2.36 / \mathrm{kg}$ of hydrogen). This is expected because of the high construction costs for the nuclear reactor. Fixed operating and maintenance costs $(\$ 0.57 / \mathrm{kg}$ of hydrogen) are relatively high because they include operation and maintenance costs for both the reactor and hydrogen production plant. Yearly variable costs $(\$ 0.28 / \mathrm{kg}$ of hydrogen $)$ include the reactor fuel cost, a reserve for unplanned equipment replacement costs, and the yearly replacement cost of the solid oxide electrolysis (SOE) cells. The cost of the SOE modules was estimated to be $\$ 200 / \mathrm{kW}$ of power to the electrolysis stack and it is assumed that $1 / 3$ of the modules are replaced annually. The feedstock cost contribution $(\$ 0.012 / \mathrm{kg}$ of hydrogen) represents the cost of the demineralized water feedstock, which feeds the electrolysis process. Although the electrolysis process also produces oxygen, which could be sold as a byproduct of the hydrogen production process, the reference HTE design does not attempt to recover the oxygen byproduct. Therefore, while the 
sale of the oxygen byproduct would lower the overall cost of the hydrogen production process, no credit for the production of oxygen was taken in this cost analysis.

The information presented in this report is intended to provide baseline hydrogen production costs for the optimized reference nuclear-driven HTE hydrogen production plant so that operating parameters and costs can be compared with other hydrogen production methods and power cycles to evaluate relative performance characteristics and plant economics. 


\section{References}

1. Herranz, L. E., Linares, J. I., and Moratilla, B. Y., "Assessment of regenerative reheating in direct Brayton power cycles for high-temperature gas-cooled reactors," Nuclear Technology, v 159, n 1, July, 2007, pp. 15-24.

2. O’Brien, J. E., Stoots, C. M., and Hawkes, G. L., "Comparison of a One-Dimensional Model of a High-Temperature Solid-Oxide Electrolysis Stack with CFD and Experimental Results," Proceedings, 2005 ASME International Mechanical Engineering Congress and Exposition, Nov. 5 - 11, Orlando, FL.

3. McKellar, M. G., O’Brien, J. E., Herring, J. S., "Commercial Scale Performance Predictions for High-Temperature Electrolysis Plants Coupled to Three Advanced Reactor Types", INL Internal Report, September 14, 2007.

4. Harvego, E. A., McKellar, M. G., O’Brien, J. E., and Herring, J. S., "Summary of ReactorCoupled HTE Modeling Sensitivity Studies," INL Internal (DOE Milestone) Report, October 26, 2006.

5. Furmanczyk, K. and Stefanich, M., "Demonstration of Very High Power Airborne AC to DC Converter," SAE Technical Paper: 2004-01-3210, Power Systems Conference, November 2004, Reno, NV, USA.

6. Surdoval, W., "Nuclear Hydrogen Initiative Semiannual Program Review", October 24, 2007, Idaho Falls, ID.

7. DOE Hydrogen Program Website, DOE H2A Analysis, http://www.hydrogen.energy.gov/h2a analysis.html

8. U.S. DOE, "H2A Central Hydrogen Production Model Users Guide”, Version 1.0.10, July 2005.

9. Richards, M. B., Shenoy, A. S., Harvego, E. A., McKellar, M. G., Peddicord, K. L., Reza, S.M.M., Coupey, J. P., "H2-MHR Pre-Conceptual Design Report: HTE-Based Plant" GAA25402, April 2006.

10. Gael D. Ulrich, "A Guide to Chemical Engineering Process Design and Economics", John Wiley and Sons, Inc., 1984.

11. Matches website (Equipment cost estimating), http://matche.com/EquipCost

12. Loh, H. P., Lyons, J., and White, C. W., "Process Equipmnet Cost Estimation: Final Report", National Energy Technoloy Center, DOE/NETL-2002/1169. 